HD1761

$G 6$

Vivin: $\# 262$

Division of Agricultural Sciences

UNIVERSITY OF CALIFORNIA

\title{
FORAGE PROCUREMENT AND USE BY THE CALIFORNIA DAIRY INDUSTRY AND SELECTED DAIRY FARMS
}

Irving F. Fellows

CALIFORNIA AGRICULTURAL EXPRIMENT STATION GIANNINI FOUNDATION OF AGRICULTURAL ECONOMICS

in cooperation with

Farm Production Economics Division

Economic Research Service, U.S.D.A.

Giannini Foundation Research Report No. 262

March 1963 


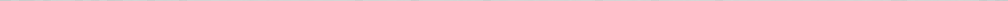




\section{ACKNOWLEDGMENTS}

It would be impractical to list individually all who contributed so much to make this study possible. Rather, the author wishes to acknowledge this cooperation by recognizing several groups. First would be the dairy ranchers of California, especially those of Marin and Sonoma counties, who provided basic data. Without exception, these men were cooperative, interested, and informative. Another group included some businessmen associated with the dairy industry. Milk dealers, feed dealers, equipment and supply handlers, truckers, and agricultural credit agencies all provided essential material to the author in his analysis. Several administrative agencles of the State of California, especially the Bureau of Milk Stabilization, provided important information and gave personal assistance in contacts with dairy ranchers. Information made available to the author by the San Francisco City Health Department made possible the selection of the study sample. Those connected with the University of California in the counties and in the Giannini Foundation contributed immeasurably through their knowledge, stimulation, and support. The Agricultural Research Service of the U. S. Department of Agriculture was the sponsoring agency for the project.

Without the assistance, Information, advice, and counsel from the many individuals in these groups, this study would not have been possible. 


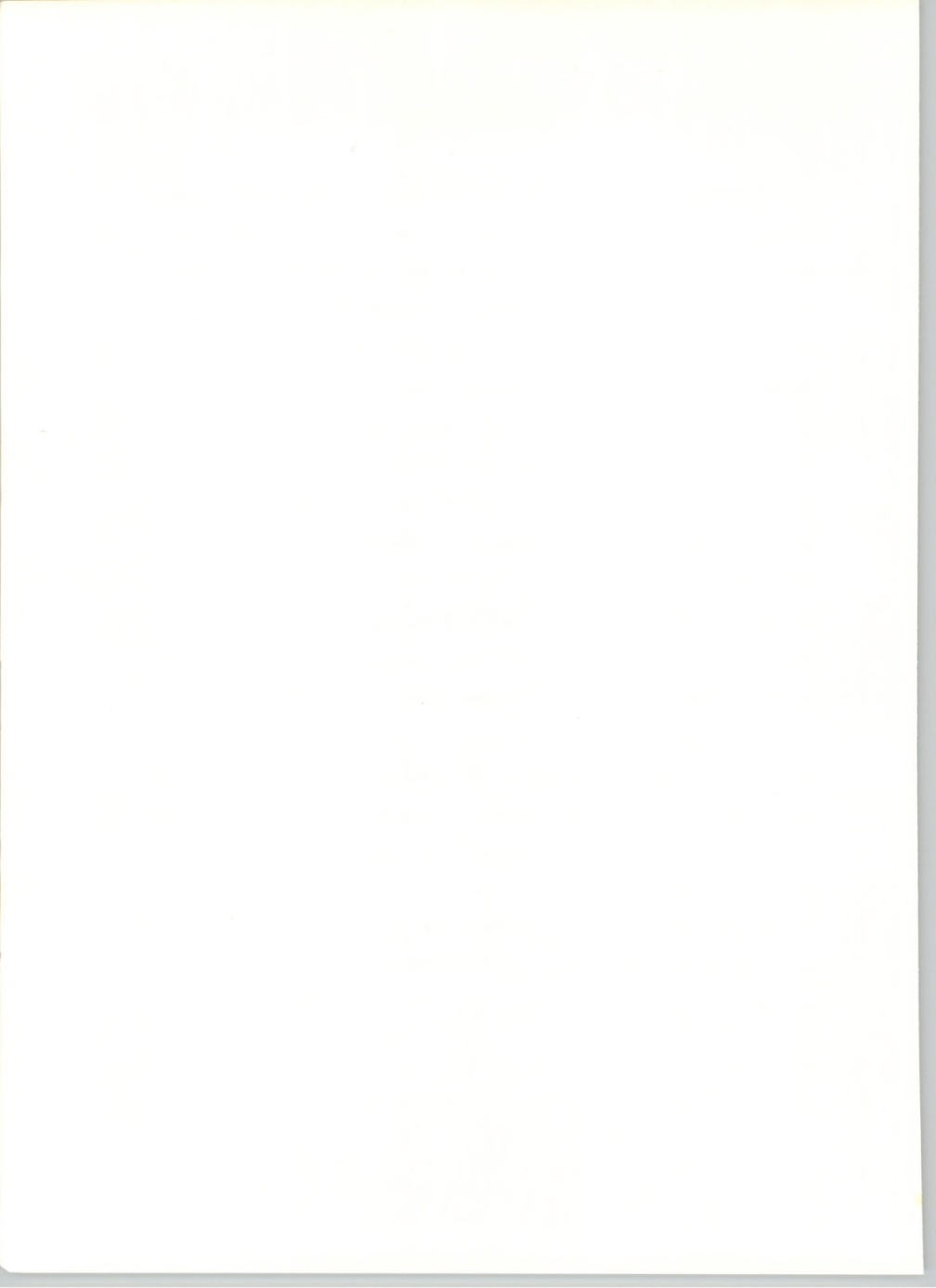


TABLE OF CONTENTS

Page

I. SETPING AND SCOPE OF THE STUDY ............... 1

A. Objectives................... 1

B. Sources of Information ............... 2

C. General Characteristics of California Dairying . . . . 3

II. ITVESTOCK FEED BALANCE . . . . . . . . . . . 7

A. Forages ................ . . 7

1. Production Trends ............. 7

2. Inshipments .............. 13

3. The Supply and Distribution .......... 14

4. Marketing .. . . . . . . . . . . 16

B. Feed Concentrates .. . . . . . . . . . 25

1. Production Trends ............. 25

2. Inshipments ............. . . 29

3. The Supply and Distribution ......... 30

4. Marketing .............. 32

III. FORAGE PROCUREMENT AND USE ON DAIRY RANCHES IN

THE NORTH BAY AREA . . . . . . . . . . . 35

A. Characteristics of the Area .......... . 35

B. The Dairy Ranches . . . . . . . . . . . 37

1. Inventory of Productive Resources . . . . . 39

2. Production Practices............. . 46

3. The Cost Structure ............ 58

4. The Returns ................ 61

5. The Flow Concept............. 66

IV. DEVELOPMENTS IN FORAGE PROCUREMENT AND USE . . . . . . . TO

A. Role of Pastures . . . . . . . . . . 70

B. Technological Changes . . . . . . . . . 75

v. SUMMARY AND CONCLUSTONS . . . . . . . . . . 79 


\section{FORAGE PROCUREMENT AND USE BY THE CALIFORNIA DAIRY INDUSTRY AND SELECTED DAIRY FARMS}

by

Irving F. Fellows $\stackrel{1}{ }$

\section{SETTING AND SCOPE OF THE STUDY}

\section{A. Objectives}

The present study is one of several which have been made or are under way at the Giannini Foundation to explore economic problems in the dairy production industry. 2/ Each study has covered a particular problem area. The emphas is to date has been on the growth and adjustment problems connected with the major expansion of milk production in the southern part of the state.

This study is primarily concerned with problems associated with forage procurement and use by the dairy industry of the state and with an examination of the organization and operation of individual farms under a system where a large part of the needed forage is purchased. Information is desired regarding the kinds and amounts of forages used by the dairy industry, their relation to other feed supplies, the marketIng techniques and costs which have developed, and the role of forage as

1/ Specialist in the Agricultural Experiment Station, University of California, and Professor of Agricultural Economics, University of Connecticut, on sabbatic leave.

2/ L. B. Fletcher and C. O. McCorkle, Jr., Growth and Adjustment of the Los Angeles Milkshed: A Study in Economics and Location, California Agricultural Experiment station Bul. 787 (Berkéley, 1962), 88p.

J. R. Devidson, "Economic Efficiency and Firm Adjustment for Market Milk Production in the Southern Metropolitan Milkshed of California" (unpublished $\mathrm{Ph} . \mathrm{D}$. dissertation, Department of Agricultural Economics, University of California, 1960), $246 \mathrm{p}$. 
a production factor and its relation to other input requirements on California dairy ranches. Such a study may point to problems in forage procurement and use within the state and may be of help to dairymen in other areas of the country where problems of land use raise questions concerning the economy of local forage production.

The specific objectives are as follows:

1. To describe for the dalry industry of the state the balance between types and sources of major feeds and feed requirements and the marketing procedures and costs which have evolved.

2. To analyze the role of forage as a productive input on dairy ranches in the central coast district and the business organization and practices which have evolved.

3. To speculate about possible changes in forage procurement and use and to evaluate the economic impact of such changes.

\section{B. Sources of Information}

The information presented in this report was obtained from three general sources--published material from state and federal agricultural agencies, a field survey of dairy farms in the study area, and contacts with individual dairymen as well as with firms that supply these dairymen. Extensive statistical information is available from the California Crop and Livestock Reporting Service. This, coupled with information from the U. S. Census of Agriculture, provides long-time trend information on the quantities of specific crops and livestock; relevant prices; disposition of products; and changes in numbers, types, and characteristics of farms. The Bureau of Milk Stabilization provides periodic information on production, production costs, consumption, prices, and 
similar milk marketing statistics. Truck and rail transportation costs and regulations are ava1lable from the California Public Utilities Commission and the Interstate Commerce Commission, respectively. These are but a few of the sources of basic information which are avallable on California agriculture in 1ts broadest sense.

A field survey of dairy ranches in Marin and Sonoma counties of the central coast district also provided material for the study. A sample of two groups was chosen from the total population. Twenty farmers were contacted within each group, and a field schedule was completed by perscnal interview with each dairyman. Descriptive data were obtained of the resources used in the dalry business, their sources, and costs.

In addition, because of the particular emphasis given to forage as a productive input, contacts were made with representative feed dealers, truckers, and growers in a larger geographic area serving the North Bay area. Forage sources, prices, transfer costs, institutional arrangements, and possible developments were obtained from this group.

\section{General Characteristics of California Dairying}

Dairying is of major importance in the agriculture of Califormia. In 1959 the sales of dairy products totaled $\$ 376$ million--12.5 percent of the total value of farm products sold (Table 1). There were nearly 1 million $(945,000)$ cows kept for milk, and they produced nearly 8 billion $(7,974,000,000)$ pounds of milk. $1 /$

1) California Crop and Livestock Reporting Service, California Dairy Industry Statistics for 1959: Manufactured Dairy Products, Milk Production, Utilization, and Prices, Special Publication No. 280 (Sacramento, 1960), 75p. 
TABLE 1

Cash Receipts from Farm Marketing

California, 1959

\begin{tabular}{|c|c|c|}
\hline Source of income & Income & $\begin{array}{l}\text { Percent } \\
\text { of total }\end{array}$ \\
\hline \multirow{3}{*}{ Plants and products } & $\begin{array}{l}\text { thousand } \\
\text { dollars }\end{array}$ & \\
\hline & & \\
\hline & 794,743 & 26.4 \\
\hline Fruit and nuts & 606,118 & 20.1 \\
\hline Vegetables and melons & 405,463 & 13.5 \\
\hline Forest, nursery, and greenhouse & 82,070 & 2.7 \\
\hline Subtotal & $1,888,394$ & 62.7 \\
\hline Livestock and products & & \\
\hline Cattle and calves & 445,173 & 14.8 \\
\hline Dairy & 375,979 & 12.5 \\
\hline Eggs & 135,004 & 4.5 \\
\hline Turkeys & 60,1143 & 2.0 \\
\hline Brollers & 31,971 & 1.0 \\
\hline Sheep and lambs & 24,359 & 0.8 \\
\hline Hogs & 17,522 & 0.6 \\
\hline Other & 32,360 & 1.1 \\
\hline Subtotal & $1,122,511$ & $37 \cdot 3$ \\
\hline Total & $3,010,905$ & 100.0 \\
\hline
\end{tabular}

Source: California Crop and Ilvestock Reporting Service, California Farm Income (Sacramento, 1960), p. 2. 
An industry of this size places California among the leading dairy states in the nation. In 1959 the state ranked sixth in number of milk cows on farms, first in average production per cow, fourth in total milk production, and third in cash receipts from farm marketing of milk and cream. But overall size is not the only distinguishing characteristic of the California dairy industry. Its unique organization and the high production efficiency of its commercial producing units may well be its outstanding features. These dairymen have earned a wide recognition for the large size of their producing units; the heavy dependence upon purchased forage; and the high output per unit of land, labor, and capital. Statewide averages do not give a satisfactory description of the organization and production practices of the dairy farms. The state is too large and the environment too varied. In the northern and eastern mountainous areas, dairying is a declining industry. The number of dairy farms and the average herd size have decreased in the recent decade. Milk production is highly seasonal and is generally supported by forage grown on each unit. At the other extreme are the "milk factories" of southern California. Because of severe competition for land for alternative uses and the high cost of Irrigation water, all hay and pasture production bas been curtailed on many dairy ranches; and a drylot or feedlot type of organization has evolved. On these dairies all feeds are purchased, alfalfa hay coming from irrigated areas 50 to 200 miles away. The milk production process becomes one of transforming purchased Inputs into the primary output--milk. Land provides a location and a minimum amount of space for the transformation process. Average herd size is estimated at about 190 cows per farm, average annual production 
per cow is over 12,000 pounds, and the total number of cows has risen over 50 percent in the last decade.

In many respects, dairying in the central coast area most nearly resembles that of commercial areas in other parts of the United States. The ranches are family operations which follow typical herd management practices, produce their own replacement stock, and have land areas which provide about three months of permanent pasture for the producing herd and year-round grazing for replacements. However, the herds are considerably larger than in other dairy areas--averaging slightly over 100 cows per farm--and practically all of the hay and green feed used is purchased from other areas within the state. 


\section{LIVESTOCK FEEDD BALANCE}

The existence and development of vast areas within the state adapted to the production of forages and grain crops have contributed greatly to the unique features of California's dairy industry. With the expansion of Irrigation facilities, thousands of acres of cropland well adapted to the production of alfalfa and feed grains have been brought under cultivation. Under the naturally arid conditions of the area, losses in quality are kept at a minimum during harvesting. Thus, the California dairyman has feeds of superior quality available from extensive producing areas nearby. The adequacy of the supplies, their use by the various livestock groups, and the marketing procedures employed are discussed in the following sections.

\section{A. Forages}

1. Production Trends $1 /$

One of California's major crop resources is the forage grown on its fields and pastures. The value of all harvested hays was estimated at $\$ 172$ million in 1959 , and to this sum must be added about $\$ 25$ million for the value of silages and other roughages. It is difficult to estimate the true value of pasturage, but some believe it to be even greater than that of hay and silage.

Alfalfa is the most important forage crop whether measured in terms of acres grown, production, or value. About 1.25 million acres are used

1/ California Crop and Livestock Reporting Service, California Field Crops Statistics, 1944-1957 (Sacramento, 1958), 47p. 1960), Idem, California Field Crops, 1960 Annual Summary (Sacramento, 
annually for alfalfa, with recent years showing a steady increase. Yields per acre have also increased steadily. The present statewide average is 4.8 tons per acre, but some growers obtain yields of 6 to 8 tons on large acreages. Total production was 5.6 million tons in 1959 (Figure 1). Most of the alfalfa is grown in the Irrigated valleys of the state. The heart of the production area is in the southern part of the San Joaquin Valley (Figure 2). Here alfalfa is often grown in conjunction with cotton farming; it is used as a cash crop on nonallotment acres and as a crop which has highly beneficial effects in a rotation. The United States Census of Agriculture showed that over 3 million tons were grown in the San Joaquin Valley in 1959. I/ Grown on 531 acres, the average yield was nearly 6 tons per acre. Both the number of acres used for the crop and the number of growers have declined since 1954, while production is nearly 4 percent greater. Over 2 million tons were sold by the growers, and much of this quantity moved onto dairy farms in the Los Angeles area (Table 2). The southern California district is the second most important producing area, with Imperial County output exceeding that of any other county in the entire state (Figure 2). Production has increased substantially in Imperial, Riverside, Santa Barbara, and San Bernardino counties while declining in counties containing the larger metropolitan areas. Nearly 90 percent of the tonnage grown is sold by the growers (Table 2).

The Sacramento Valley is the remaining major producing area of surplus alfalfa (Figure 2). Nearly 600,000 tons are grown here and about 450,000 tons are sold (Table 2). This is the chief supply area for

I/ U. S. Bureau of the Census, 1959 Census of Agriculture--Preliminary, separate California county reports, 1960. 
Figure 1. Production of Major Hay Crops, Corn and Sorghum Silage

(in Hay Equivalent Terms), California, 1950-1959

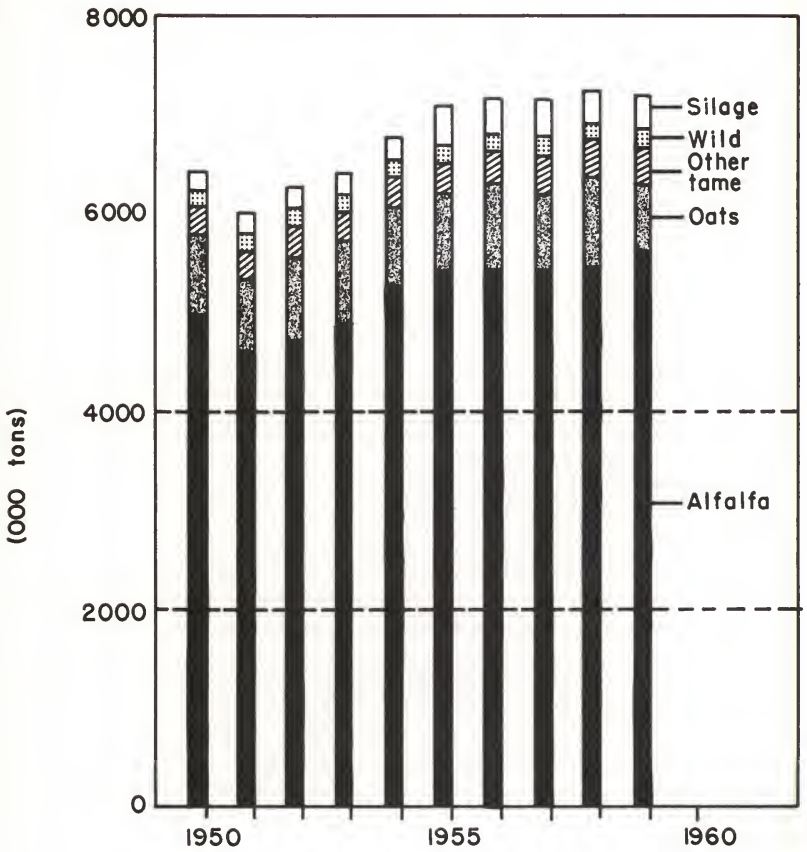

Sources:

California Crop and Livestock Reporting Service, California Field Crops Statistics, 1944-57 (Sacramento, 1958), 47p.

Idem, California Field Crops 1960 Annual Summary (Sacramento, 
Figure 2. Tons of Alfalfa Produced by Counties in Three Major Producing Districts, California, 1959

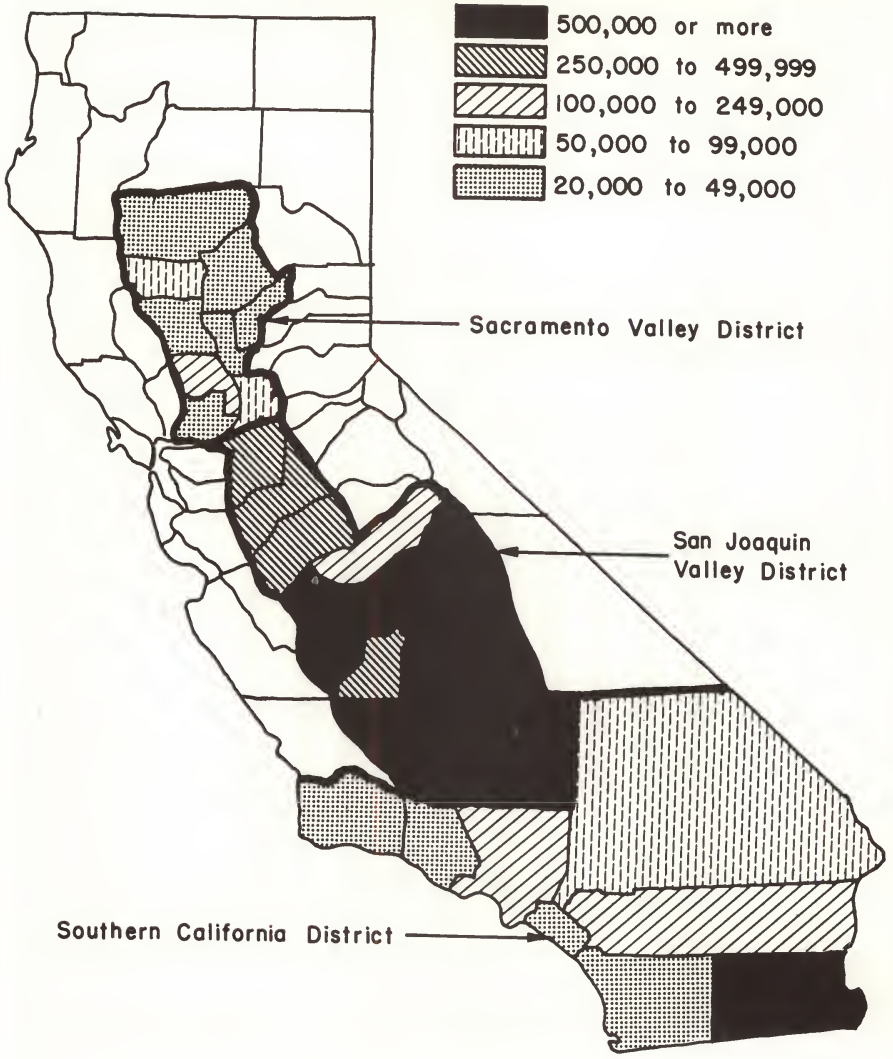

Source: U. S. Bureau of the Census, 1959 Census of Agriculture--

Preliminary, separate California county reports, 1961. 
ThBTS 2

Mlfalfa and Mlfalfa Mixtures Gut for Hay and for Dehydrgting, Three Areas by Countles Calleornts, 1959 and 1954 .

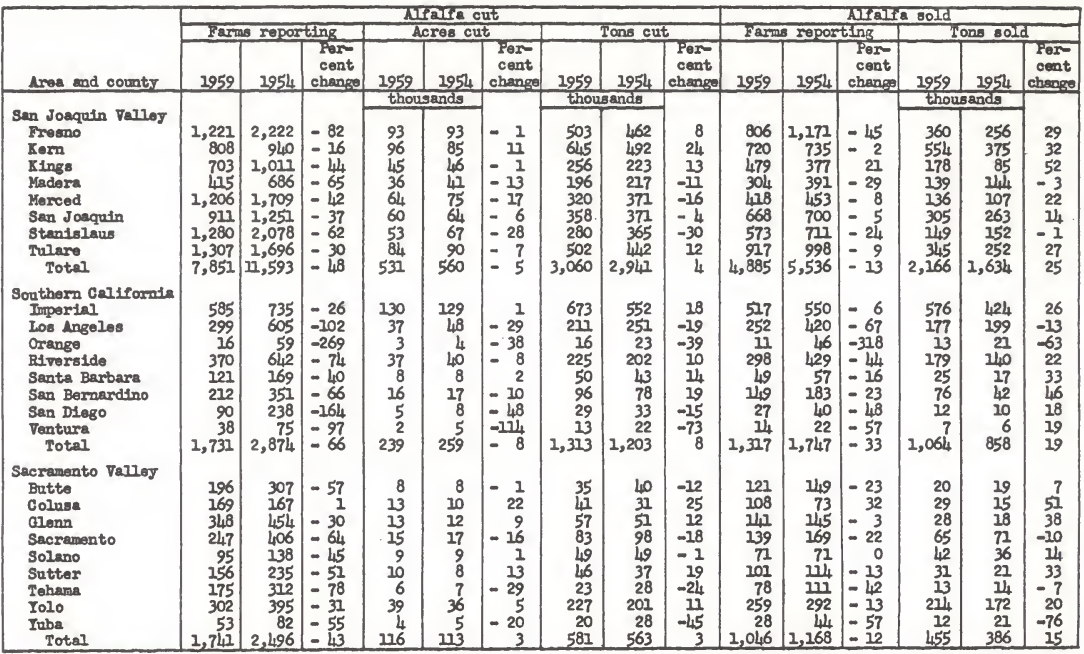

a/ Percentages and totels will not check exactly, ss they were computed from actual data, whereas this table shows date rounded to nearest thousend.

Sourcez U. S. Bureau of the Census, 1959 Census of Agriculture-Prel1minary, separate Callfarnia county reports, 1961. 
dairymen in the central coast district. The major expansion in alfalfa production in this Valley is taking place in the southern area:

Production of alfalfa under irrigated conditions requires very careful management, especially in the southern desert areas where alkaline and saline conditions are common. The most frequent method of irrigation is called the check-strip technique whereby water flows slowly from the water source at one end of each strip to the other end. The strip may be from 30 to 50 feet wide, with slight mounds in the surface to form a waterbreak along each edge. Some growers are adjusting the width of each strip to facilitate the use of new harvesting equipment. The length of the strip depends upon soil type. A slope of 0.2 feet per 100 feet is typical, but this, too, depends upon soil conditions. The establishment of these physical conditions usually calls for extensive and accurate land preparation. In certain soil types, leaching of excess minerals must be accomplished before a successful crop can be grown. At all times, care must be exercised to prevent a deterioration of the soil conditions through poor irrigation techniques.

Four to six cuttings are harvested annually in most cases; some operators in the southern areas obtain even more. When the crop is removed immediately, either for dehydrating or for green-chop feed, elght cuttings may be obtained, because the delay between cutting and the following irrigation is at a minimum. Most of the crop is sun-cured in windrows, baled in wire-tied bales which weigh about 120 to 140 pounds, and stacked at the roadside for transport. About 10 percent of the crop is chopped green for feeding or for alfalfa-meal production. Some alfalfa is now going into cubes or wafers, but this use is largely in an exploratory phase. 
Oats harvested as oat hay ranks second as a source of forage. Because of adverse weather conditions, production in 1959 was only 672,000 tons, substantially below the normal of 850,000 tons (F1gure 1 ). Oat hay is grown over the winter period in many counties of the state, espectally in regions where the flelds are quite rolling and cannot be Irrigated easily and where the winter rains provide adequate water. Counties in the central coast district and throughout the Central Valley are the main supply areas.

Other tame hays and wild hay complete the supply of forage harvested as hay. These two types furnish about 7 percent of the total supply (F1gure 1).

Since 1950, the production of corn silage and sorghum silage has Increased substantially, but, on a hay-equivalent basis, these provided only 5 percent of the total forage supply in 1959 (Figure 1). Because of their bulkiness per unit of weight, they are ususlly fed in the area where they are produced.

\section{Inshipments}

Alfalfa bay moves into California by truck from the nearby states, especially Arizona. Data concerning this movement are incomplete, having been collected only since February, 1961, by the California Bureau of Plant Quarantine on border crossings at inspection stations. Data for February through June were made available to the author by personal correspondence and show a total of 75,570 tons. If this five-month period were extrapolated to a full year, the total would be approximately 175,000 tons. This estimate checks well with sample data for the 1953-1955 period, 
when average annual imports were estimated at 159,000 tons. I/ No rail imports of hay were shown in the Interstate Commerce Comnission material. [/

\section{The Supply and Distribution}

The combination of hay production--corrected for beginning and ending inventories for the crop year and for alfalfa diverted to meal--plus production of silages in hay-equivalent terms, plus net inshipments, constitutes the supply of forage available for livestock feed in any year. A summary of these data for the crop year beginning in May, 1959, shows a total of over 7 million tons available for animal use (Table 3). These data do not include certain roughages used by animals as a substitute for forage. Wet beet pulp, cottonseed hulls, and various vegetable and fruit waste products are also fed to animals, primarily beef, hogs, and sheep. As data on many of these items are not available and as emphasis in this report is on the dairy industry, which uses only a small amount, statistics for these roughages are not included.

The number of roughage-consuming animal units in California reached a record high of 4,594,000 in 1959. $3 /$ This level is 34 percent above the 1950 number, and the growth has been relatively stable during the period. The sharpest change in number of animals occurred in beef animals, for

I/ Robert S. McGlothlin, Hay and Feed Grains in the West: Supplies, Utilization, and Interstate Movement, Arizona Agricultural Experiment Station Bul. 289 (Tucson, 1957), 38p.

2/ U. S. Interstate Commerce Commission, Carload Waybill Statistics, 1959: State-to-State Distribution, Products of Agriculture, Traffic, and Revenue; One Percent Sample of Terminations in the Year, 1959, 1960, 92p.

3/ U. S. Agricultural Research Service, Animal Units of Livestock Fed Annually, 1909 to 1959, Statistical Bulletin 271, 1960, p. 9. 
TABLE 3

Supply and Distribution of Storable Forage in Terms of Hay Equivalent California, May 1, 1959, to Apr11 30, 1960

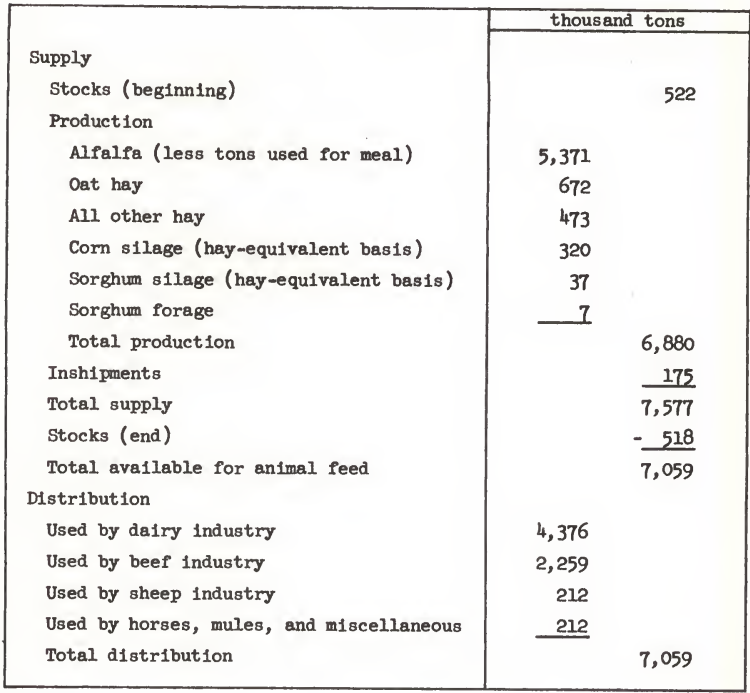

Sources:

California Crop and Livestock Reporting Service, California Field Crops Stat1st1cs, 1944-1957 (Sacramento, 1958), $47 \mathrm{p}$.

Idem, California Field Crops 1960 Annual Summary (Sacramento, 1960), 4p.

Idem, California Annual Livestock Report: Summary for 1959, Inventorles January 1, 1960 (Sacramento, 1960), 31p. 
which the 1959 level is almost double that of 1950 (Table 4). All dairy cattle increased by 18 percent in the same period. Sheep and lambs increased slightly, and hogs and draft stock decreased by about 50 percent.

of the forage avallable for these classes of livestock, dairy stock used 62 percent of the total. Beef, which used a substantial amount of pasture, required 32 percent. Sheep and the combination pf all other classes each required 3 pereent.

\section{Marketing}

A well-organized marketing complex has developed to move forages from the growers to the consumer. Of course, many operators grow roughage on their own cropland for their own stock. But the typical arrangement is for a crop grower to produce alfalfa hay in conjunction with other crops and move it through trade channels.

Transfer from the grower, especially to dairy ranchers, is accomplished by four different systems. Most important in terms of volume distributed are the feed and hay dealers. These are the typical proprietary companies which have grown with the livestock industries and have serviced them with concentrates. A natural addition to the service is the procurement and distribution of hay. Many different techniques are used in carrying out this function. Personal contacts which have grown up over the years may play an important part. A grower may have sold his hay to the same company for many years. A buyer typically buys from the same company. Some dairy ranchers actually know the grower personally and may have had hay from the same farm for years. Occasionally such close ties exist between rancher and grower that even information on the relative quality of a particular cutting may be transferred. Nevertheless, 
TABLE 4

Inventories of Livestock, January 1, by Classes

California, 1950-1959

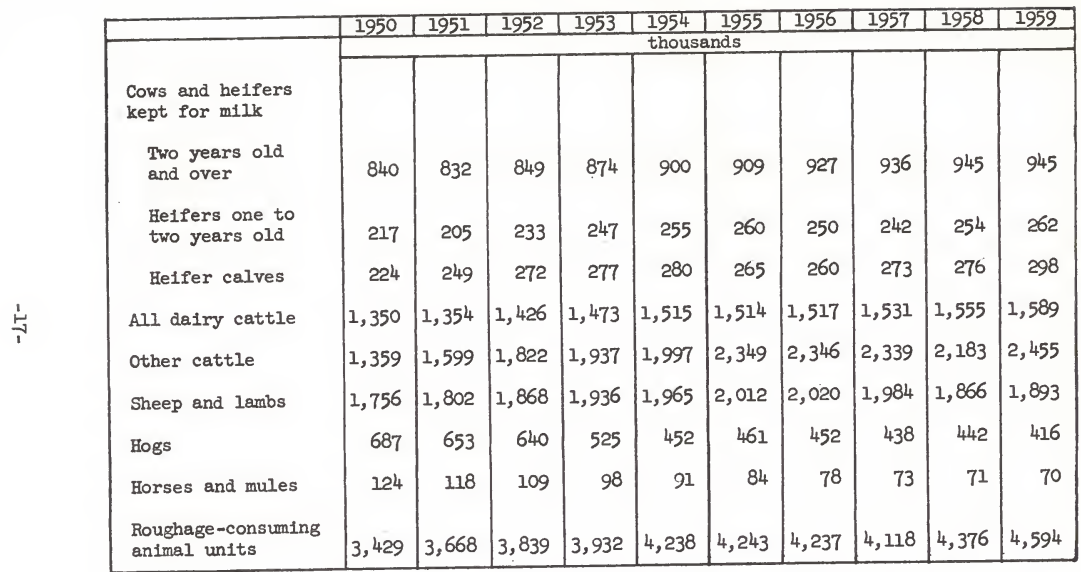

Sources:

California Crop and Iivestock Reporting Service, California Annual Livestock Report:

Summary for 1959, Inventories January 1, 1960 (Sacramento, 1960), 31p.

U. S. Agricultural Research Service, Animal Units of Livestock Fed Annually, 1909 to 1959 , Statistical Bulletin 271, 1960, 12p. 
most dairymen prefer that the dealer act as the agent in achieving the transfer. Dairy ranchers are insistent upon a given quality of hay and will reject any hay delivered that is of an inferior quality.

Very often one of the company men is both hay buyer and seller. During the growing season this man spends much of his time in the producing areas buying hay for his company. He contacts the grower who has harvested and stacked at the roadside a given lot of hay, inspects and samples the hay by visual evaluation and laboratory analysis of physical and chemical composition, and makes a bid subject to certain limits discovered in the analyses. Buyers from other companies probably have bid on the same lot. These bids, together with weekly information published by the Crop and Livestock Reporting Service on crop situations, crop movement, and prices, give the grower an indication of the market conditions.

Once a contract for a lot has been made, the bay may go directly to a particular ranch even though title shifted to the company. Through his contacts as a hay salesman, the buyer knows what type of hay is desired by a given rancher. To a considerable extent, this knowledge served to condition his bid. Based upon his knowledge of the outlet opportunity and of the supply conditions for a particular class of hay, his bid may have been higher or lower than an estimate of the general market.

Particularly in the Los Angeles area, hay arrives from growers on a consignment basis to a hay dealer. Once it is at his location, he attempts to sell to a rancher, using his knowledge of the outlet possibilities. The load is then directed to the ranch for delivery. Additional loads may then move directly to the ranch to fill commitments of the sale. These dealers obtain $\$ 1.50$ to $\$ 2.00$ per ton for the services rendered. 
A second method of distribution is through cooperatives. Several grower cooperatives have been formed to serve as outlets for alfalfa and to aid in stabilizing the growers' market position. Each cooperative acts as an agent for its members in selling their hay, especially to trucker-dealers. One large cooperative performs these services for a cost of slightly over $\$ 1.00$ per ton.

Trucker-dealers are a third group in this marketing system. Many truckers are licensed as hay brokers for the purpose of buying hay directly from growers or from grower cooperatives. They take title to the hay and move it either directly to ranchers who are established customers or to the truckers' locations in the dairy area, where dairymen may call, inspect, and bid on the hay.

As a fourth alternative, dairymen may go directly to growers or grower cooperatives for their supply. This alternative has been declining in use, for dairymen prefer to spend their time in the management of their herds. They also find it desirable to have a responsible agent to whom to turn in case of dissatisfaction.

Practically all hay is moved by truck. This has the advantage of direct shipment from the fleld to the ranch. All loading and unloading into stacks or sheds at dairy ranches are done by the trucker and his crew. Transport over the public highways of California is under strict regulation by the Department of Motor Vehicles and the Public Utilities Commission. Maximum length and height of load are of significance in trucking hay because these, rather than weight restrictions, usually place limitations on the load. A 65-foot overall length is permitted on certain truck roads, but on most roads a 60-foot limit prevails. As most dairy ranches are located on side roads, the 60-foot limit is a practical upper 
limit. Height of load is limited to $13 \frac{1}{2}$ feet. The typical hauling carrier is a five-axle unit with a double-axle tractor pulling a single-axle semitrailer and a two-axle full trailer. Both trailers are of the platform body type. A full load will weigh about 22 tons. Other types of equipment are used in handling green, chopped alfalfa. When this forage goes to a ranch, the trucker places it directly into the feed racks.

For the public carriers, rates, conditions of pickup and delivery, and similar considerations are specified by the Public Utilities Commission (Table 5).I/ The prescribed rates are based upon "constructive miles, " that is, the land mile adjusted for conditions which would make the driving more costly than if it were straight and level. Constructive mileage between all important points in the state has been developed for the Public Utility Commission. As an example, the "constructive miles" from Petaluma, a major supply center for dairy ranches in the North Bay area, to zones in the Sacramento and San Joaquin valleys are shown in Figure 3. Similar zones could be constructed about any other consumption center. Zones are used to eliminate the problem of obtaining exact mileage from farm to farm. If the trucker-dealer takes title to the hay, these Commission conditions do not apply; but, of course, the motor vehicle department limitations do. Hay prices received by growers vary among seasons and among months in any one season (Table 6). In the last ten years, the seasonal average price for all alfalfa has varied from $\$ 19.70$ per ton to $\$ 31.30$. 2/ The

I) California Public Utilities Commission, Minimum Rate Tariff, No. 2 (San Francisco, 1961), pp. 51 EE and 511.

2) California Crop and Livestock Reporting Service, Califormia Prices Received by Farmers for Farm Commodities, Monthly and Season Average Prices, 1908-1960, by Harley M. Brewer (Sacramento, 1960), 55p. 
TABLE 5.

Rates Applicable by Class of Constructive Mile in the Transportation of Baled Hay by Public Carrier on California Highways

\begin{tabular}{|c|c|c|c|c|c|}
\hline \multicolumn{2}{|c|}{ Mileage } & \multirow{2}{*}{$\begin{array}{l}\text { Cents per } 100 \\
\text { pounds for } \\
\text { loads of over } \\
40,000 \text { pounds }\end{array}$} & \multicolumn{2}{|c|}{ Mileage } & \multirow{2}{*}{$\begin{array}{l}\text { Cents per } 100 \\
\text { pounds for } \\
\text { loads of over } \\
40,000 \text { pounds }\end{array}$} \\
\hline Over & $\begin{array}{l}\text { But not } \\
\text { over }\end{array}$ & & Over & $\begin{array}{l}\text { But not } \\
\text { over }\end{array}$ & \\
\hline 50 & 60 & 19.5 & 190 & 200 & 34 \\
\hline 60 & 70 & 20.5 & 200 & 220 & 36 \\
\hline 70 & 80 & 22 & 220 & 240 & 38 \\
\hline 80 & 90 & 23 & 240 & 260 & 40 \\
\hline 90 & 100 & 24 & 260 & 280 & 42 \\
\hline 100 & 110 & 25 & 280 & 300 & 44 \\
\hline 110 & 120 & 26 & 300 & 325 & 46 \\
\hline 120 & 130 & 27 & 325 & 350 & 48 \\
\hline 130 & 140 & 28 & 350 & 375 & 51 \\
\hline 140 & 150 & 29 & 375 & 400 & 53 \\
\hline 150 & 160 & 30 & 400 & 425 & 55 \\
\hline 160 & 170 & 31 & 425 & 450 & 57 \\
\hline 170 & 180 & 32 & 450 & 475 & 59 \\
\hline 180 & 190 & 33 & 475 & 500 & 62 \\
\hline
\end{tabular}

Source: California Public Utilities Commission, Minimum Rate Tariff, No. 2 (San Francisco, 1961). 
Figure 3. Constructive Mileage Zones Between Petaluma and Areas in
the Sacramento and San Joaquin Valleys, California, 1960

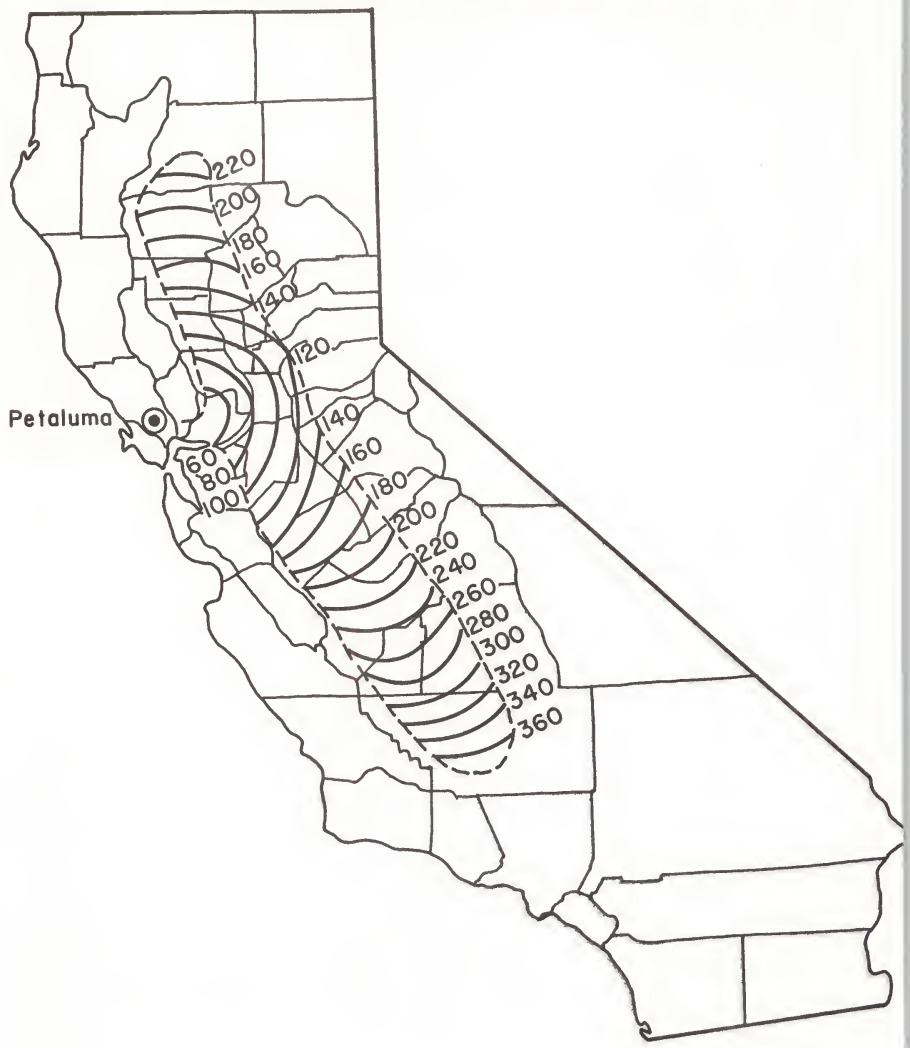


TABLE 6

Monthly and Seasonal Average Price Received by Growers for Baled Alfalfa Hay, California, 1950-1959

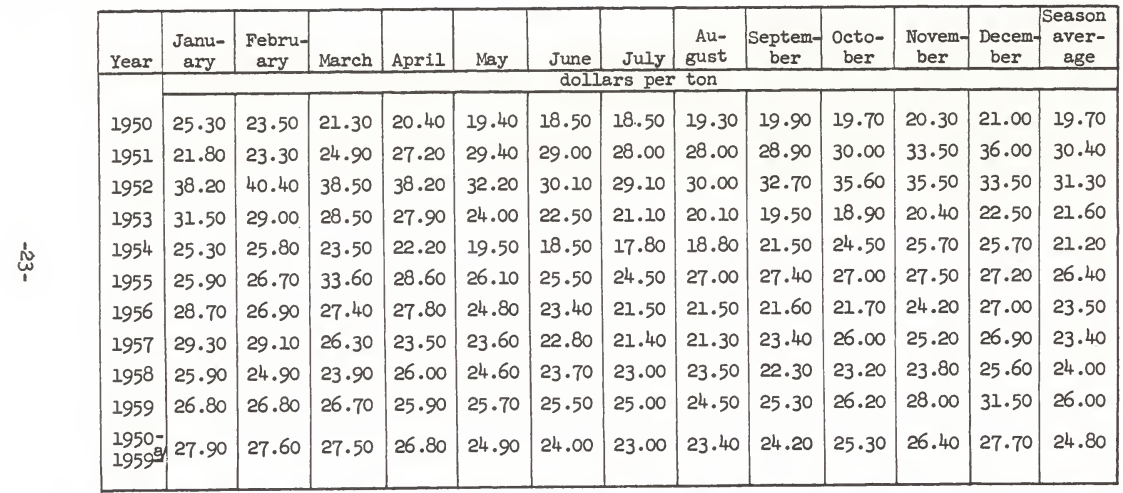

a) Simple average by months.

Source: California Crop and Livestock Reporting Service, California Prices Received by Farmers for Farm Commodities, Monthly and Season Average Prices, 1908-1960, by Harley M. Brewer (Sacramento, 1960), 55p. 
simple average for the period was $\$ 24.80$. Such price changes are highly associated with crop production variation. Grade differences affect the price of individual lots. Rain damage may occur on the first cutting, especially in the Sacramento Valley. The presence of weeds, other grasses, and insect damage, as well as the effects of poor harvesting techniques, will lower the price.

Monthly variations are even greater than those in the seasonal averages. In most years there is a definite decline as the harvest season progresses. In the period under discussion, the low point occurred in July in 6 of the 10 years and in August in 2. This type of price movement frequently occurs in agricultural crops as the harvest season progresses, but in this case it also reflects the high preference of dairymen for the earlier cuttings of alfalfa.

The grower price plus transportation costs, which vary with distance but w1ll usually be from $\$ 5.00$ to $\$ 8.00$ per ton, plus the dealer charges of approximately $\$ 2.00$, will be the delivered cost of hay at the farm. For example, dealers' selling prices dellvered to the customer in Petaluma during the first week of July in 1959 and in 1960 were $\$ 32.00$ to $\$ 33.00$ and $\$ 30.00$ to $\$ 31.50$, respectively, for U. S. No. 1 alfalfa. In Los Angeles the 1959 price for the same period was $\$ 31.00$ to $\$ 33.00$, and the 1960 price was $\$ 32.00$ to $\$ 34.00 . I /$ Assuming 45 therms of energy per 100 pounds of hay, because of the high quality, the cost per 100 therms ranged from $\$ 3.56$ to $\$ 3.78$ at dairy ranches in these years. In other parts of the

1/ Federal-State Market News Service, Alfalfa Hay Market Report (Sacramento: 1950-1959, weekly issues). 
nation, similar unit costs are possible, especially through the use of forage substitutes. For example, if beet pulp or c1trus pulp costs about $\$ 55.00$ per ton at the farm, the cost per 100 therms would be approximately $\$ 3.68$. Information available to most dairymen would permit similar comparisons for other alternative feeds.

\section{B. Feed Concentrates}

Because of the close relationship between concentrates and forages in the total feed requirements and the need for a comprehensive view of feed utilization, a brief summary of concentrates supplies and distribution is given here.

1. Production Trends $1 /$

California produces in the form of feed concentrates and commercial by-products about two-thirds of the quantity used by livestock and industry. Outstripping all other locally grown feed grains is barley. Nearly 2 million acres are harvested annually. This amount has been reasonably stable in the last decade. Total production has risen, however, because of higher ylelds per acre from improvements in cultural practices and from higher yielding varieties (Figure 4). Barley is grown throughout the state, but the Central Valley is the major supply area. Here it combines well with other crops, for 1 is grown over the winter period and is harvested sufficiently early in the season to be followed by same annual crop.

Next in importance from a production standpoint are grain sorghums (Figure 4). The acreage used for sorghums has risen steadily, especially

If California Crop and Livestock Reporting Service, California Field Crops Statistics . . . . Idem, California Field Crops .... 
Figure 4. Production of Major Feed Grains, California, 1950-1959

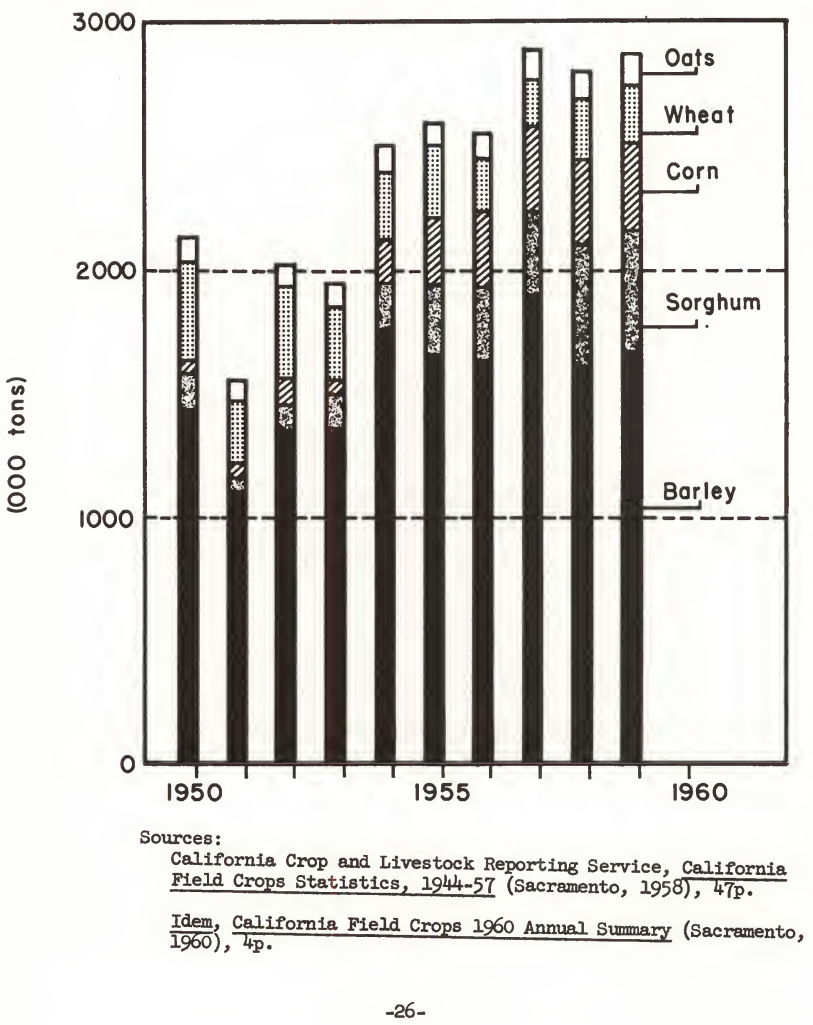


since 1955; over one-quarter of a million acres are now harvested annually. Though grain sorghums were formerly a dry-land crop, more of the acreage is now grown with irrigation, especially in the Central Valley. Yields per acre have increased rapidly over the past decade. Average yields per acre of 41 bushels in 1950 have been increased to 67 bushels in 1960. Although this crop provides nearly one-fourth as much total output as barley, it uses only one-seventh the amount of land.

Corn for grain ranks third as a source of feed grains (Figure 4). A sharp increase in the acreage used for grain corn occurred in the mid1950 's along with much higher ylelds per acre. These shifts resulted from improvements in the technology of production and the restriction of cotton acreage allotments in the San Joaquin Valley. Many cotton growers turned to corn as a substitute cash crop for nonallotment acreage. Unless new developments occur in production techniques, the annual acreage will be tied closely to the cotton program.

A long-time downward trend has brought wheat acreage to less than 400,000 acres. Barley has been the chlef competitor in the drier areas, and other cash crops in irrigated sections. Average wheat yields per acre are up 10 percent from 1950 levels, and annual production is about $8 \mathrm{mil}-$ Iion bushels (Figure 4).

Although over 700,000 acres are planted to oats, approximately 70 percent of this is used for hay. Oats for grain have been relatively stable in the last 10 years, with production averaging about 6 million bushels annually (Figure 4). Yields per acre have increased slightly over the period.

Cottonseed, sugar beets, alfalfa, and citrus crops are the most significant crop sources of by-product concentrates feeds. The production of 
cottonseed has varied greatly in the last decade and is related to the cotton allotment program. In 1960 nearly 1 million acres of cotton were grown, but this was below the 1.3 million acres of the mid-1950's. Annual cottonseed production has been about 750,000 tons in recent years. From this, cake and meal are used as concentrates in animal feeds. Production of sugar beets has been quite stable in the last decade at approximately 4 million tons annually. Both the number of acres and yield per acre were a.lso quite consistent from year to year. Much of this consistency was due to a program of contracts with processors. Contracts have been expanded following restriction of Cuban imports, and planted acreage has risen. Sugar beet pulp is an important by-product feed. From every ton of beets, about 1,600 pounds of wet beet pulp or 400 to 600 pounds of dry pulp are obtained. Dried beet pulp is used extensively as an ingredient in dairy concentrates. The production of alfalfa meal has risen steadily in recent years, and this trend will continue with the recent installation of additional plant capacity. In 1959 output reached 240,000 tons. I/ Citrus pulp for feeding has increased steadily as more citrus is processed for juices. Over 2.3 million tons of citrus were harvested in the 1958-59 crop season, and 30 percent was processed. $2 /$ From the processed fraction, it is estimated that 58,000 tons of pulp were produced. $3 /$

If U. S. Agricultural Marketing Service, Alfalfa Meal Production by States, $1960,2 \mathrm{p}$.

2/ Sunkist Growers, Inc., Statistical Information on the Citrus Fruit Industry, 1960 Supplement (Los Angeles, 1960), pp. 3-8.

3/ Estimate provided by personal contact with Sunkist Growers, Inc., Market Research Department. 


\section{Inshipments}

Inshipments by rail, truck, and water provide the remaining third of the needed supply. Feed grains dominate inshipments, with receipts by truck and rail estimated at approximately 1.65 million tons in 1959.1 Rail shipments accounted for nearly 70 percent of this tonnage, as most of the shipments originate in grain areas in the central part of the United States. Texas provided over one-third of all the feed grains shipped in; Kansas, Nebraska, and Oklahoma were major supply areas also. The intermountain states were major suppliers of wheat. Sorghum grain ranked flrst on the basis of tonnage shipped, wheat was second, and corn was third. A relatively small quantity of oats, barley, and other grains completed inshipments. Actually, outshipments of barley exceeded inshipments, for some California barley is highly prized for malting purposes. Truck shipments originated in 24 states and Canada and Mexico, but the bulk of the feed was from nearby states and Texas. Shipments of feed grains by boat showed a net outflow of 365,000 tons, as these grains found foreign markets. 2 /

By-product feed statistics are far less complete than those for feed grains. Carload waybill statistics showed net imports of 298,000 tons by rail, but truck import statistics are nonexistent. Doubtless there is only a small quantity imported by truck. Waterborne tonnages showing a

If U. S. Interstate Commerce Commission, op. cit.

Federal-State Market News Service, Inbound Truck Passings--Season Totals (Sacramento, July, 1961), p. 2.

2/ U. S. Department of the Army, Corps of Engineers, Waterborne Commerce of the United States, Calendar Year 1959, Part 4, 1960, 199p. 
net import of 413,000 tons were reported for 1959. A.lmost 80 percent of this quantity was copra, which is used extensively in dairy concentrates feed.

\section{The Supply and Distribution}

The combination of production, net inshipments, and net movement in and out of storage constitutes the supply of feed concentrates available for all uses in any year. A comprehensive study of this supply and its distribution was made by King $1 /$ for the crop year beginning October 1, 1957 (Table 7). This is the latest period for which some of the data were available. Wherever information was available for the 1959 year, comparisons were made, and the data were found to be highly similar. For example, the production of feed grains was only 2 percent higher in 1959 than in 1958 , and net imports of all feeds were identical.

Approximately 90 percent of the feed concentrates were used for animal feed--5.1 million tons in the 1958 period. Of this total, 45 percent was required for the poultry industry. Beef and dairy requirements were nearly identical at 22 and 21 percent, respectively. The remaining 12 percent was needed for hogs, sheep, and miscellaneous requirements.

Grain-consuming animal units reached an all-time high in 1959--at 5.9 million units. 2/ This was 24 percent over the 1950 level. There has been a steady increase in the number of units, and this trend is expected to continue. The demand for feed concentrates is expected to put pressure on the supply for the foreseeable future.

1) Gordon A. King, Regional Supply and Distribution of Feed, 1957-58, University of California, Giannini Foundation Research Report No. 248 (Berkeley, 1961), 79p.

2f U. S. Agricultural Research Service, op. cit. 
TABLE 7

Supply and Utilization of Concentrates

California, 1958 and 1959

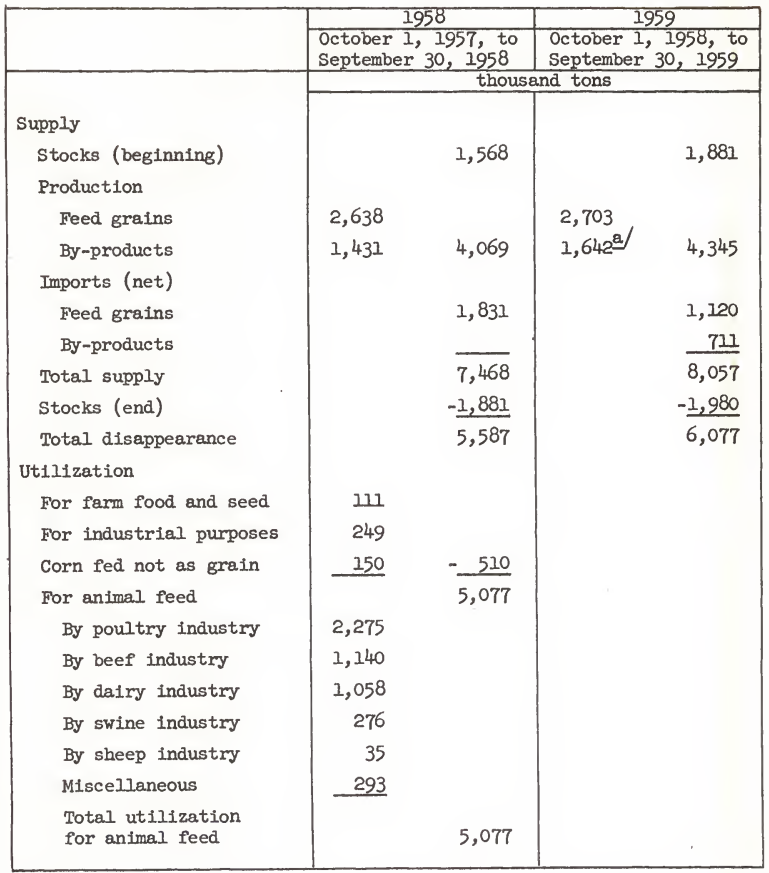

a) Includes citrus and beet pulp not included in data by King.

Source: Calculated from data provided by Gordon A. King, some of which are published in his Regional Supply and Distribution of Feed, 195758, University of California, Giannini Foundation Research Report No. 248 (Berkeley, 1961), pp. 19 and 22. 


\section{Marketing}

A high proportion of all feed concentrates moves to the consuming farms, ranches, and feedlots through regular market channels, including feed dealers and feed mill operators. Some of the large feedlot operators buy directly from feed growers and industrial processors and prepare the feed mix at their own plants at their lots. Others buy part of the ingredients, especially feed grains, directly from the growers and then have a mix prepared at a commerclal feed mill or combine the grains with a highly concentrated commercial mixture during the feeding procedures.

Almost universally, dairymen buy their feed concentrates through a proprietary or cooperative feed dealer and mill operator. California dairymen place great emphasis on having a uniform feed which is consistent throughout the year. Many have developed their own formulas, and the $\mathrm{mix}$ is made on an individual basis with little or no variation in ingredients regardless of price movements. Over the last few years, there has been a movement toward the inclusion of more sorghum grains and a slight reduction in crude protein. But the major shift has been in the physical texture of the $\mathrm{mix}$ to improve its characteristics to flow in mechanical feeders and to permit cows to consume more in a given time period.

Intrastate transportation of feed is largely by truck, although considerable rail movement occurs over longer distances, and some interior and coastwise shipping takes place. Truck movement over the highways is subject to close control as to maximum weight and length of the hauling rig, conditions of operation, and charges for the service. 
The most common for-hire carrier for feed grains is the five-axle bulk unit consisting of a two-axle tractor pulling a single-axle semitrailer and a two-axle full trailer, both of the hopper or bottom-dumping type. These units move feed grains directly from a loading point in the grower's fields, often from a "bank-out" unit, to the storage elevators or from the fields or elevators to the feed mills. Charges are on the basis of "constructive miles," which have been determined between all major points in the state. Rates are fixed by the Public Utility Commission and are related to kind and form of product, weight limitations (both minimum and maximum), distance (including a concept of time), and several other factors in the form of assessments for a typical service. I] For example, for the truck unit mentioned above, which would have a capacity of over 40,000 pounds, the bulk rate per 100 pounds would be 21 cents for a hauling distance of over 100 miles but less than 110 miles. Rules concerning field pickup, stops in transit, delays, and demurrage are specific for the commodity.

The movement of feed concentrates from mills to dairy ranches is primarily in bulk in trucks owned by the mill operator. Usually a close supplier-user tie exists between the feed dealer and the dairyman. This may be on an informal basis, or contracts for the annual supply may be placed on the basis of a low bid to specifications. Although relatively few feed dealers service a local area, competition for each customer is quite keen within the limitations of widely known ingredient supply conditions, prices, and fixed transport costs. Therefore, the competitive

If California Public Utilities Commission, op. cit. 
emphasis is on service to the customer. Bulk deliveries encourage batch mixing to the dairyman's own formula and, through the scheduling of deliveries, has removed the procurement and handing problem from the rancher. Trucks of an 8- to 12-ton capacity are used for nearby deliveries; 16-ton capacity trucks are used on longer hauls. Bulk delivery and scheduling service add about $\$ 1.50$ per ton to the ingredient cost to dairymen whose ranches are within a 25 -mile radius and about $\$ 2.00$ to those within a 25- to 50-mile radius. A $\$ 4.00$ charge is typical for distances of over 100 miles one way. However, the total price per ton is considered by the purchaser, and often the delivery cost component is adjusted by the seller in order to secure the account.

Feed grain prices have generally moved downward during the decade. The 1960 price indexes received by California growers for barley and sorghum grains were 84 and 76, respectively, compared with a 1950 index of 100 for each. A similar but less extensive price movement has also occurred in practically all other feed ingredients. The cost of mixed feed has reflected this general movement. In 1960, California dairies paid from $\$ 65$ to $\$ 75$ per ton for a mixed feed of 16- to 18-percent protein delivered in bulk at the farm. Following is a schedule of the average annual cost per hundredweight of mixed dairy ration (16 percent) for the state during the 10 years under review.

\begin{tabular}{|c|c|c|c|}
\hline Year & Dollars & Year & Dollars \\
\hline 1950 & 3.25 & 1955 & 3.41 \\
1951 & 3.76 & 1956 & 3.37 \\
1952 & 4.19 & 1957 & 3.35 \\
1953 & 3.90 & 1958 & 3.19 \\
1954 & 3.45 & 1959 & 3.38 \\
\hline
\end{tabular}

Source: U. S. Agricultural Marketing Service, Milk Production, 1960, p. 13. 


\section{FORAGE PROCUREMENT AND USE ON DAIRY RANCHES}

IN THE NORTH BAY AREA

\section{A. Characteristics of the Area}

The availability of a uniform and high-quality supply of alfalfa hay and the existence of a well-developed marketing system for 1ts distribution have had a marked effect upon the structure of California dairy farms. In this section, patterns of resource organization and production practices which have evolved through individual farm adjustments to this situation are described and analyzed by means of an examination of representative farm businesses.

Marin and Sonoma counties were chosen as the area for this detailed study. These counties lie in the coastal ranges of the state directly north of San Francisco, the most distant point about 80 miles from that city. The metropolitan Bay area with a population of between 3 and 4 million is the market outlet for milk. These counties were chosen because the market situation and physical environment are reasonably similar to many other sections of the nation and because these two counties are an important part of the Bay area milkshed. Large business units which are operated at high technical efficiency and which depend upon the extensive use of purchased forage are found here. For these reasons, it was hoped that a study of dairy business management in these counties would yield important contributions toward the solution of management problems of dairies in the area and in other sections of the country.

of a total of 1.3 million acres in these two counties, nearly 1 million acres are in farms. Much of the farmland is on steep, rolling 
hills, largely free from brush and trees and used for pasture by the producing herds and replacement stock. A few interior valleys exist. About one-tenth of the total acreage is used for harvested crops, primarily oat hay and other tame hays. Very little irrigating is done. The hills, dry and brown for much of the year, turn green in February with the winter rains and the rapid growth of annual grasses. Excellent pasture is obtained for the milking herd for three to four months; then the annual grasses mature and remain dry in the rainless periods, and the pastures are used by the replacement and dry stock. Water is scarce. It is provided by wells and springs for the homes and milk rooms, but dairymen with larger herds store water in farm ponds for washing stables and use by cattle.

Not long ago, dairymen in these counties had small herds, grew much of their own forage, and marketed cream. All is changed now. The buildings formerly used for the hay and cows still remain, but they are now usually used for storage of the hay supply for use during the winter rainy period. A new complex of buildings has been erected, with the milking center as the heart. Cows remain out of doors the entire year.

Reporting services indicated that 83,100 cows and heifers two years old or over were kept for milk in the two counties in 1959.1 Milk production was 5.9 million hundredweight. The blended average annual price was $\$ 5.59$ per hundredweight for 3.8-percent-butterfat milk

If County of Marin, Agricultural Commissioner, Annual Livestock and Agrícultural Crop Report, 1960 (San Rafael, California, 1961), 5p. Also, County of Sonoma, Agricultural Commissioner, Agricultural Crop Report, 1960 (Santa Rosa, California, 1961), 10p. 
at the city plant. Approximately 8.5 percent was manufacturing milk which averaged $\$ 3.23$ per hundredweight. Total income from the sale of milk was $\$ 33,026,000$.

\section{B. The Dairy Ranches}

Records are available in the San Francisco City Health Department giving certain descriptive information on all dairy farms which ship milk into that market from Sonoma and Marin counties. The only exceptions are dairies which produce exclusively for local consumption, and the number of such farms is known with considerable accuracy. It was estimated that 89 percent of all dairies were represented. This was deemed to be an adequate universe both for general descriptive purposes and for sampling.

The universe consisted of 413 records, with data on herd size available on 394. Size of the producing herd ranged from 19 to 639. When grouped by 10-cow class intervals, the most common herd size was 100 to 109; nearly as common was the 80 to 89 size (Figure 5). There was no heavy concentration in any particular interval at the higher levels.

A sample was drawn from the universe for additional study by direct contact with the farm operators. A selection was made from each of two groups--one consisting of herds of approximately 100 cows and the other consisting of herds of approximately 200 cows. A sufficient number of farms were drawn to permit the completion of 20 schedules in each group. Information on farm organization and operation was obtained. 
F1gure 5. Frequency Distribution of Dairy Herds by Number of Cows, Marin and Sonoma Counties, California, 1960

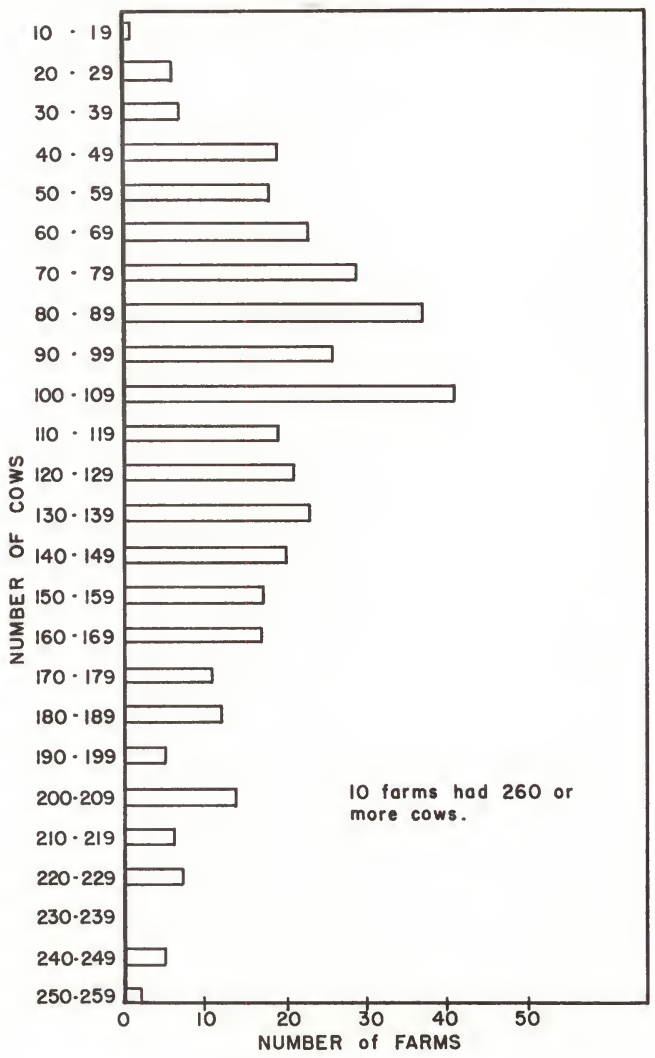




\section{Inventory of Productive Resources}

An inventory was obtained of the physical quantities and values of productive resources used on dairy ranches in Groups I and II, exclusive of feed stocks on hand. The average per farm for dairies in each group is given in Table 8 .

All of the dairymen in the sample used land in addition to that area required for the ranch headquarters. The average number of acres owned per farm was 240 and 710, respectively, for Groups I and II (Table 9). Additional land, most of which was used for pasture, was rented by 15 of the 40 ranches. Little cropland was used; six ranchers in Group I and five in Group II raised crops on a total of 861 acres. Five used irrigation to increase yields. Corn for silage, alfalfa, and oat hay were the crops grown. Pastures have been established on most old cropland and, together with the natural pastures, constitute the major use for land. With owned and rented areas, the average total acreage available per cow was 2.8 and 4.8 for Groups I and II, respectively. These averages were 1.9 and 2.6 per roughage-consuming animal unit which gives consideration to the replacement stock on farms. An arbitrary value of $\$ 200$ per acre was applied to all crop and pastureland and $\$ 50$ per acre for wasteland. Many ranchers stated that portions of their ranches could probably be sold for much more per acre for nonagricultural uses, but they believed an agricultural value of $\$ 200$ per acre for all usable land was a realistic figure. That sum was adopted mainly to give comparative data rather than to reflect market values. The average value of land used per farm was calculated as $\$ 64,000$ for 
TABLE 8

Average Investment by Type of Resources Used Per Farm by Farm-Size Groups, Marin and Sonoma Counties California, 1960

\begin{tabular}{|l|r|r|}
\hline \multicolumn{1}{|c|}{ Type of resource } & Group I & Group II $]$ \\
\hline \multirow{2}{*}{ Land } & \multicolumn{2}{|c|}{ dollars } \\
\cline { 2 - 3 } Livestock & 64,160 & 139,862 \\
Buildings and facilities & 34,552 & 63,916 \\
Equipment & 32,045 & 41,672 \\
Total & $\frac{7,708}{8,270}$ \\
Total investment per cow & 138,465 & $\frac{253,720}{2}$ \\
Total investment per animal unit & 1,204 & 1,288 \\
& 948 & 909 \\
\hline
\end{tabular}

a) Consists of approximately 100 cows per farm.

b/ Consists of approximately 200 cows per farm. 


\section{TABLE 9}

Average Acreage and Investment in Land Used Per Farm by Farm-Size Groups, Marin and Sonoma Counties

California, 1960

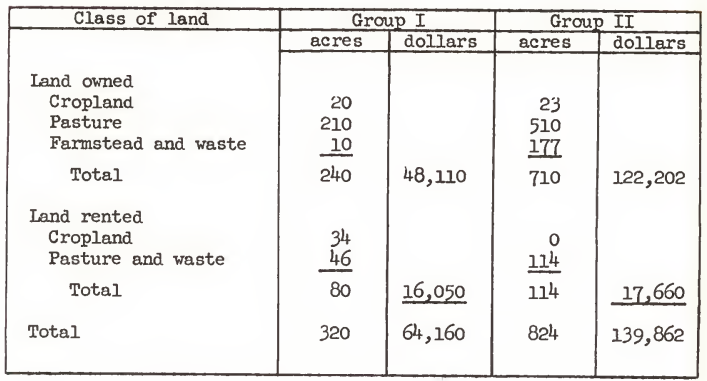


the farms in Group I and $\$ 140,000$ for those in Group II. About 25 percent of the land value was acquired by renting in the former case and 13 percent in the latter case.

All ranchers in the sample were specialized dairymen. The only other classes of livestock found were horses, used for rounding up cattle in the hills; beef bulls, used in the pastures with old heifers; and an occasional beef animal for family food. Field contacts showed that the ranchers had altered their herd size from that shown in records of the previous year. Most had increased their herd; a few had decreased. The average number of cows per farm was 115 for Group I and 197 for Group II (Table 10). Young stock were raised by all these dairymen. Usually there was a sufficient number to meet replacement needs, even with a high culling rate. A few of the dairymen bought some replacement stock. A value of $\$ 250$ per cow was assigned and was used for all farms for comparative purposes. This was below the market value for a top producer in good health but reflects owner evaluation on the entire herd. About 40 percent of the cows were Jerseys or Guernseys of medium size. Young stock were assigned values of $\$ 125$ per head for heifers one year old or over which have never freshened and of $\$ 50$ for heifers less than one year old. On these bases, the value of herds ranged from $\$ 24,000$ to $\$ 104,000$. The average value of livestock per farm was $\$ 35,000$ and $\$ 64,000$, respectively, for the two groups.

The investment in buildings and associated facilities estimated by the ranchers at the time of the interviews averaged $\$ 32,000$ per farm in Group I and about $\$ 42,000$ per farm in Group II (Table 11). The most important element of this investment was the milking center, including 
TABLE 10

Average Number and Investment in Livestock Per Farm by Farm Size Groups, Marin and Sonoma Counties

California, 1960

\begin{tabular}{|l|r|r|r|r|}
\hline \multicolumn{1}{|c|}{ Class of livestock } & \multicolumn{2}{|c|}{ Group I } & \multicolumn{2}{c|}{ Group II } \\
\hline & number & dollars & number & dollars \\
\cline { 2 - 5 } Cows (milking or have milked) & 115 & 28,762 & 197 & 49,218 \\
Heifers (over one year) & 34 & 4,300 & 87 & 10,711 \\
Heifers (one year or less) & 27 & 1,340 & 72 & 3,595 \\
Others & $\frac{1}{177}$ & $\frac{150}{34,552}$ & $\frac{2}{358}$ & $\frac{392}{63,916}$ \\
Total & 146 & & 279 & \\
Animal units a/ & 165 & & 326 & \\
Roughage-eating animal units & & & \\
\end{tabular}

a/ Based on conversion factors used by the California Extension Service.

b/ Based on conversion factors used by R. D. Jennings, Animal Units of Livestock Fed Annually, 1909-1955, U. S. Department of Agriculture Statistical Bulletin No. 194, 1956, p. 6. 


\section{TABLE 11}

Average Investment in Buildings and Pacilities and Equipment Per Farm, by Farm-Size Groups, Marin and Sonoma Counties California, 1960

\begin{tabular}{|c|c|c|c|c|}
\hline & \multicolumn{2}{|c|}{ Group I } & \multicolumn{2}{|c|}{ Group II } \\
\hline & \multicolumn{4}{|c|}{ dollars } \\
\hline $\begin{array}{l}\text { Buildings and facilities } \\
\text { Milking center } \\
\text { Storage barns, corrals, } \\
\text { feed racks, lanes, etc. } \\
\text { Water system }\end{array}$ & 32,045 & $\begin{array}{r}(16,340) \\
(13,583) \\
(2,122)\end{array}$ & 41,672 & $\begin{array}{r}(18,970) \\
(18,162) \\
(4,540)\end{array}$ \\
\hline Equipment & 7,708 & & 8,270 & \\
\hline Total & 39,753 & & 49,942 & \\
\hline $\begin{array}{l}\text { Total per cow } \\
\text { Total per animal unit }\end{array}$ & $\begin{array}{l}346 \\
272\end{array}$ & & $\begin{array}{l}254 \\
179\end{array}$ & \\
\hline
\end{tabular}


milking equipment, bulk tanks for milk storage, and bulk concentrates equipment. These centers represented investments of $\$ 10,000$ to $\$ 30,000$. About two-thirds of them were of recent construction and were fitted with feeding and milk-handling devices to reduce labor requirements. Others were developed by remodeling older, double-row milking barns. Practically all of the centers use the California level-floor stable where batches of cows are brought into stanchions, prepared for milking, milked, and removed either by backing out or passing through the stanchion. Lanes guide the cows to a holding area, where washing is done on some of the farms and from which they move into the milking area as needed. Most of the ranchers wash the cows thoroughly once they are in the milking line and while they are fed concentrates. After a preparatory period, the milking machine is put on. In the larger units specialized milkers do the final preparatory work and milk the cows; other workers move, wash, and feed the cows. However, on the ranches in the study area, the division of labor was not nearly as precise as in the Los Angeles area.

Under health regulations cows cannot remain in the milking areas for any extended period of time. Observance of this rule, coupled with a thorough washing after every milking, leads to exceptionally clean milking centers. A good water system is of major importance because of the large quantities used. Investments in wells, pumps, dams, etc., ranged from $\$ 800$ to $\$ 14,000$. The large units usually required greater investments, especially in dams to store water throughout the summer and fall dry periods.

With the exception of concentrates, all feeding is done away from the milking area. Typically, baled hay is fed in feed racks adjacent 
to hay which is piled in the open for the dry weather period and in covered areas for rainy periods. Recently, new feed barns have been built on the larger units to reduce the labor of feeding. Racks have been incorporated into these storage areas to protect the cows while eating and to reduce labor in the handling of hay. Investment in fences, racks, paved and graveled areas, and hay storage facilities cumulates rapidly. The average investment in these approached the investment in the milking center.

Investment in general farming equipment is kept at a minimum. On most ranches this is limited to a general-purpose tractor, manureremoval equipment, wagons, fencing equipment, and a light truck or jeep. Crop production requires additional production and harvesting equipment, although baling is often done on a custom basis. Manure is frequently removed from the farm or spread on the hillsides by a custom operator. The average investment in general equipment was $\$ 7,700$ on Group I farms and $\$ 8,300$ on Group II farms (Table 11).

In the investment required for buildings and equipment, substantial economies appear as size of herd increases. On the basis of average data, investment in these resources was $\$ 346$ per cow on the Group I ranches and $\$ 254$ per cow on the Group II ranches. The average investment per cow in land is confused by many factors. Historically, these operators have acquired huge blocks of land, much of which is not usable, but they tend to maintain these areas in one holding.

\section{Production Practices}

Many of the production techniques used by dairymen in the study area have already been discussed. In this section, emphasis will be 
given to labor utilization, particularly as it is influenced by forage practices, and to forage procurement and use.

The labor used on these dairy ranches was drawn from the farm family and hired sources. In Group I, 17 of the 20 ranchers hired some labor throughout the year, and 9 of these had regular hired milkers. The average quantity of hired labor measured on a man-equivalent basis was 0.6 per farm. This was 28 percent of the total man-equivalents available per farm. Family workers provided the balance to give an average of 2.2 total man-equivalents per farm (Table 12). Variation in the quantity of labor among the farms was from a low of 1.6 to a high of 3.4. In the former case, cows per man-equivalent were 59; in the latter case (an operator who grew irrigated crops), the same measure was 40. Several factors influence these relationships. The number and kinds of livestock and the quantity of forage grown could be quantified and were highly related to the amount of labor. I/ But such forces as effectiveness of work methods, convenience of the buildings and milking center, physical capacity, and basic drive of the workmen could not be incorporated in such a relationship.

A description of the practices used on the ranch having the lowest labor requirements in Group I may be helpful to dairymen in other parts of the country to indicate how the practices used permit such high cow numbers per man. The labor force consists of the operator, medium age and in good health; a 14-year-old son, a fine helper when not in school;

1/ Variations in these factors were associated with 68 percent of the variability in size of the labor force. 
Average Quantity of Labor by Sources Used Per Farm

by Farm-Size Groups, Marin and Sonoma Counties

California, 1960

\begin{tabular}{|c|c|c|c|c|}
\hline Sources of labor & \multicolumn{2}{|c|}{ Group I } & \multicolumn{2}{|c|}{ Group II } \\
\hline & $\begin{array}{c}\text { man- } \\
\text { equivalent }\end{array}$ & percent & $\begin{array}{c}\text { man- } \\
\text { equivalent a/ }\end{array}$ & percent \\
\hline $\begin{array}{c}\text { Family } \\
\text { Operator } \\
\text { Others }\end{array}$ & $\begin{array}{c}1.20 \mathrm{~b} / \\
.40\end{array}$ & $\begin{array}{l}54 \\
18\end{array}$ & $\begin{array}{c}1.30 \mathrm{~b} / \\
.21\end{array}$ & $\begin{array}{r}36 \\
6\end{array}$ \\
\hline $\begin{array}{l}\text { Hired } \\
\text { Regular } \\
\text { Part time }\end{array}$ & $\begin{array}{l}.45 \\
.19 \\
\end{array}$ & $\begin{array}{r}20 \\
8 \\
\end{array}$ & $\begin{array}{l}2.05 \\
.07 \\
\end{array}$ & $\begin{array}{r}56 \\
2 \\
\end{array}$ \\
\hline Total & 2.24 & 100 & 3.63 & 100 \\
\hline $\begin{array}{l}\text { Cows per man-a/ } \\
\text { equivalent- } \\
\text { Animal units per man- } \\
\text { equivalenta] }\end{array}$ & $\begin{array}{l}51 \\
65\end{array}$ & & $\begin{array}{l}54 \\
77\end{array}$ & \\
\hline
\end{tabular}

a) Man-equivalent means the worker's annual output equivalent to that of an able-bodied man in regular days of farm work.

b/ When two or more men were equal in the management function, they were all considered operators. 
and the operator's wife, who frequently assisted by feeding calves and by driving the feed truck. Labor is hired only to replace the operator during his two-week holiday and on special days during the year. Custom services are used for whitewashing the buildings and clipping cows. Artificial breeding is used for the producing herd.

This operator has a farm of 130 acres, all of which are used for pasture except for 3 acres in the farmstead, lanes and corrals, and hay storage area. He has a herd of 95 cows and 80 young stock. Young an1mals, separated into three age groups, are fed in pens but can move freely from the barn into open corrals with hayracks. Older replacement stock is pastured the year round on hill pastures. A beef bull is pastured with those which are mature enough to be bred. Except for three months of the year, when the milking herd is pastured in flelds near the barn, they are in a corral and are fed in racks with hay hauled from nearby stacks. The herd is milked twice daily. The operator begins morning chores at 5:15 a.m. by driving the herd into a holding corral which leads into a small holding area in the milking center. There are eight stanchions arranged as in a stanchion-type barn, with the floor practically level. Each stanchion has a feed hopper arranged to catch concentrates metered out by the operator from small bins below an auger leading from a bulk storage bin. The cows move into the interior holding area and into the stanchions for milking. After milking, each cow backs out of the stanchion and goes to the feed corrals outside. This operator, as did others, stressed the cooperative aspects of cows seeing spaces open up in the milking line and moving rapidy into them. The operator uses four single milking units and a pipeline system. He prepares four cows while four others are milking, but each 
stanchion is handled individually and milking time can be adjusted to the particular cow. On the day of the interview he milked 88 cows in 2 hours and 22 minutes. These are high-producing cows $(11,731$ pounds of milk, 460 pounds of fat) with a good health record. The milking techniques were excellent. Cleaning of the milking equipment followed immediately and was accomplished by an automatic system. All milking jobs were completed by 8:30 a.m. Afternoon milking begins at 4:00 p.m. and is completed at 7:00 p.m.

When the son is not in school, he feeds calves toward the end of each milking period and then washes the entire stable and outside approaches. He also assists with feeding hay during the day. During the school period, he helps with the afternoon and evening chores.

Each day, the operator feeds the cows and does any required maintenance work on the buildings and equipment. Manure in the holding area and lanes is scrapedinto a pile from which it is spread on pastures during the late summer.

In summary, this operator's labor is spent almost entirely on the herd itself. With delivery of all stored feed from off-farm sources, his daily concern is with milking, feeding, and maintenance for the cows and young stock.

In Group II, all operators hired one or more regular milkers. Hired workers constituted nearly 60 percent of the total supply (Table 12). These men frequently were specialized to the extent that their work was confined to those tasks associated with the milking process. They were scheduled for a $3-1 / 4$ to $3-3 / 4$ hour working period each milking, and each man was expected to handle about 90 cows during this period. Their working agreements called for two Sundays free per month and a two-week 
vacation annually. Generally, the operator substituted for the milker during these periods. For the remainder of the time, he managed the business through the use of well-kept records and did the maintenance work required for the herd and the ranch.

The average output of the labor force was greater in Group II than in Group I, and instances of outstanding performance occurred more often. On one ranch a crew of three men--the operator and two regular workers-plus a part-time man one-third time handled a herd of 238 cows and 500 young stock. Cows per man-equivalent were 71 , and animal units per manequivalent were 141. With the exception of pasture, no feed was grown; and all purchased feeds were placed into feed barns or stacks and into automatic feeders by the delivery agent.

The 40 dairy ranches included in the sample used over 31,000 tons of forage during the course of the feeding year. Of this, 90.3 percent was purchased. In Group I, an average of 574 tons of hay equivalent was used per farm; 83 percent of this was alfalfa hay brought to the area from hay-producing regions (Table 13). A few tons were grain hay purchased from the local areas. Six operators grew forage, and a total of 1,418 tons of hay equivalent was produced. In none of these cases was production sufficient for the entire herd. Frequently, home-grown forage was used by the replacement and dry stock, while alfalfa hay was purchased for the milk cows.

On Group II ranches, alfalfa was practically the only forage purchased. Most of these purchases were in the form of baled hay; however, two ranchers bought some green, chopped alfalfa, and two fed their milking herds entirely on cubed alfalfa hay. Five of the ranchers harvested forage; three of these produced considerable quantities, but none met 
TABIE 13

Average Quantities of Hay Equivalent Per Farm by Source and Farm-Size Groups, Marin and Sonoma Counties California, 1959-60

\begin{tabular}{|c|c|c|c|c|}
\hline Source and type & \multicolumn{2}{|c|}{ Group I } & \multicolumn{2}{|c|}{ Group II } \\
\hline & tons & percent & tons & percent \\
\hline Purchased & & & & \\
\hline Alfalfa hay & 473 & 83 & 865 & 87 \\
\hline Grain hay & 30 & 5 & 8 & 1 \\
\hline Green, chopped alfalfa & 0 & 0 & 40 & 4 \\
\hline Growm & & & & \\
\hline All types & 71 & 12 & 81 & 8 \\
\hline Total & 574 & 100 & 994 & 100 \\
\hline $\begin{array}{l}\text { Tons of hay equivalent per } \\
\text { hay-eating animal unit }\end{array}$ & 4.0 & & 3.8 & \\
\hline
\end{tabular}


the full requirements of his herd. In total, they harvested 1,620 tons of hay equivalent in the form of grain hay and corn silage. The average tons of hay equivalent used per farm in this group was 994 . All but 8 percent was purchased.

In Group I, the average tons of hay equivalent used per hay-eating animal unit was 4.0 , with a standard deviation of .64 tons (Table 13 ). Thus, about two-thirds of all the ranchers fed between 3.4 and 4.6 tons per animal unit. The variation was greater in Group II. Here the average was 3.8 tons of hay equivalent per hay-eating animal unit, and the standard deviation was .99 tons. Thus, two-thirds of the ranchers in this group fed between 2.8 and 4.8 tons per unit.

The quantity of hay equivalent used by the milking herd is largely fed during a nine-month period. From about June 15 to February 15, the entire forage requirements of the milking herds are provided from forage stored for this purpose. In February, pastures begin to furnish some of the requirements; and in March, April, and May a substantial part of forage needs are met by the pastures. Dry hay is available during these months, but the cows generally reduce their intake materially. In mid-June, the pastures dry rapidly, and soon the milking herds are on a full feeding of stored forage. Dry stock and the replacement stock continue to obtain most of their forage requirements from the pastures throughout the year.

Data from the Bureau of Milk Stabilization have been summarized for a six-year peribd to show the relative importance of major feeds as a source of total digestible nutrients on a sample of dairy herds in the North Bay area (Figure 6). The cyclical contribution of pastures 
Figure 6. Relative Amount of Total Digestible Nutrients Furnished by Pasture, Alfalfa Hay, and Concentrates, North Bay Area, California, 1955-1960

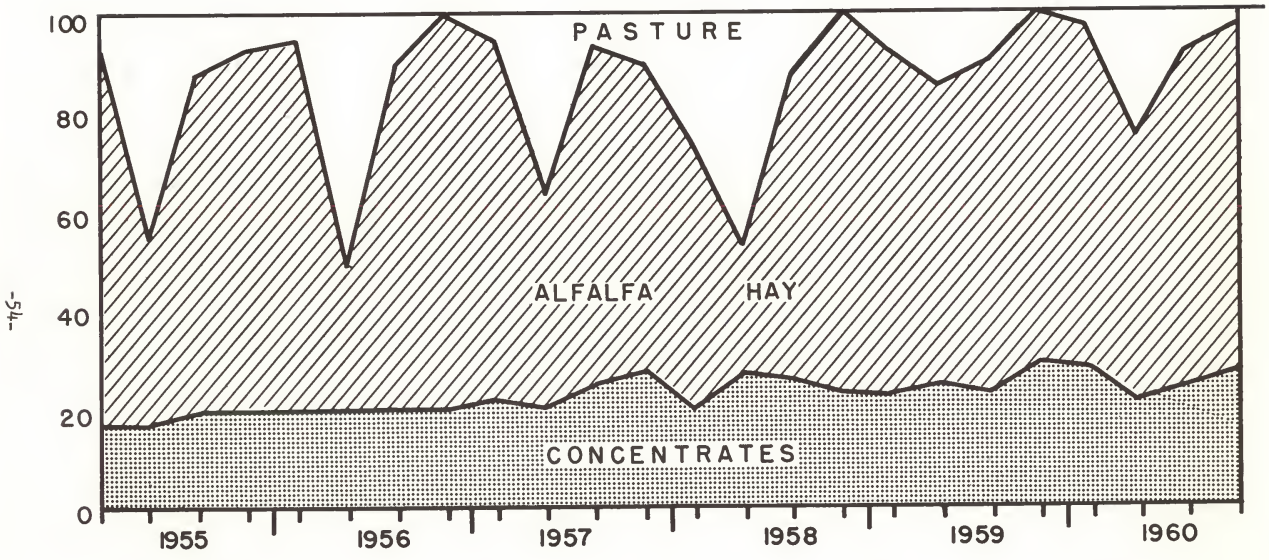

Source: California Crop and L1vestock Reporting Service, Bureau of M1lk Stabilization, Survey of Dairy Production Costs (Sacramento, quarterly, 1955-1960). 
is shown, as well as the variation from year to year due to weather conditions. In some years, as much as 50 percent of the total digesttble nutrients was obtained from pastures during the optimum growing perind. In 1959, however, only 15 percent was obtained.

One other important trend shown is the continuing upward movement in the relative importance of concentrates as a source of feed nutrients. Concentrates feeding per cow has been increasing throughout the state over time, but there has been a considerable rise since 1956. $\underline{I}$ Dairy ranchers in the sample area feed concentrates roughly in proportion to the milk produced per cow. Cows are divided into three or four classes according to the quantity of milk produced daily and are marked in some distinguishable way for quick recognition. Many of the ranchers use different colored tape to form a band around the tail. A revision of the feeding schedule is made monthly or whenever a particular animal shifts materially in her performance. The schedule may be based upon butterfat production or upon volume of milk. A typical schedule is as follows:

$\begin{array}{cr}\text { Gallons of milk } & \text { Pounds of con } \\ & 6 \\ 3 & 8 \\ 4 & 10\end{array}$

On this basis the rate of feeding increases as production increases. Adjustments in the schedule are made for high producers, cows nearing

I/ U. S. Department of Agriculture, Milk Production, 1955-1959, Statistical Bulletin No. 282, 1960, 30p. Also, U. S. Agricultural Marketing Service, Rations Fed Cows, 1944, and subsequent annual issues through 1954 . 
the end of lactation, and the availability of pasture. Some ranchers did not decrease concentrates when the herd was on pasture, but most operators stated that the cows would reduce their intake by 5 to 20 percent. The rate of feeding concentrates and milk production is also influenced by the contract under which the dairyman is marketing. Whenever seasonal variation in production diverges from the daily quota, some adjustment can be achieved by decreasing or increasing the rate of feeding concentrates.

Price movements in hay or concentrates do not bring much adjustment in the quantity fed. Hay is fed on a free-choice basis, and reJected quantities are removed from the racks for use by dry cows, young stock, and other livestock. Dairymen generally buy first-and second-cutting alfalfa which would grade U. S. No. 1 and No. 2. A few choose later cuttings. Several buy lower grades of alfalfa and chop it. Although all dairymen know that the price of alfalfa generally declines during the harvesting season, they nevertheless buy the early cutting. However, they stock an adequate supply in June and July to carry them through the year, thus avoiding a frequent rise in price during the winter months. There is practically no "carry-over from year to year, so little attempt is made to adjust to the yearly price change. In the period from 1958 through 1960, the price per ton of hay equivalent to U. S. No. I delivered into storage at farms in the Petaluma district varied from a low of $\$ 29.50$ in August, 1958, to a high of $\$ 44.50$ in January, 1960 (Figure 7). The variation in these years 
Figure 7. Semimonthly Average Price Per Ton of Alfalfa Hay Equivalent to United States No. 1 Delivered at Farms in Petaluma Area, California, 1958, 1959, 1960

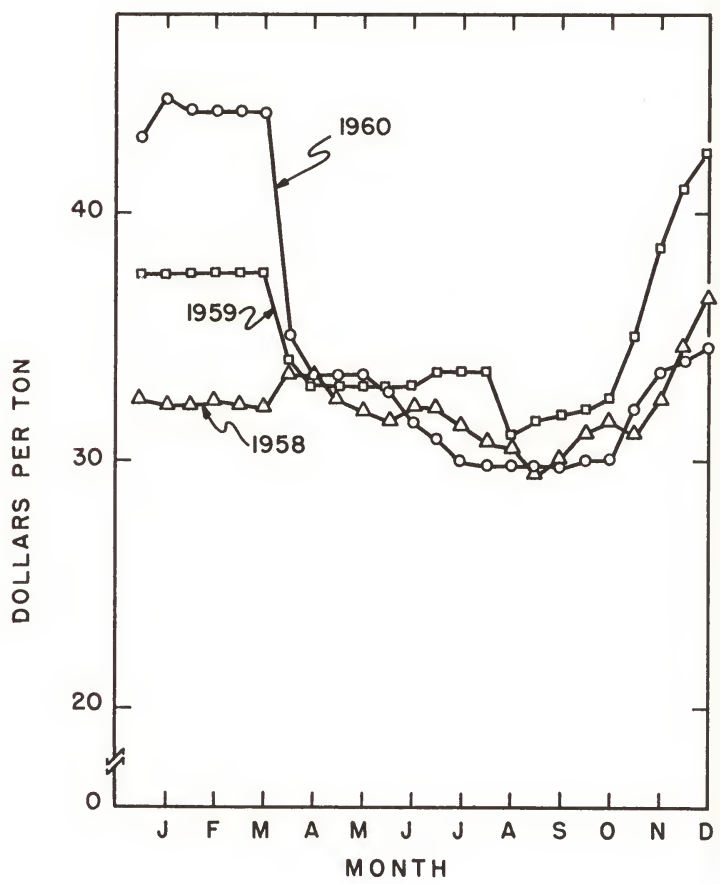

Source: Federal State Market News Service, Alfalfa Hay Market Report (Sacramento, weekly, 1958, 1959, 1960). 
indicates the effect of crop yields upon market price. The high prices at the end of the 1959 season and the beginning of the 1960 period are part of the same crop-year influence.

\section{The Cost Structure}

To discuss the cost structure on these dairy ranches, two major categories have been established and defined. The first category, annual cash operating costs, includes all costs which occur throughout the year in the continued functioning of the business; the second category, annual noncash costs, includes interest and depreciation on resources owned by the operator. These categories differ from the variable and fixed cost divisions used frequently by economists.

Annual cash operating costs are discussed in three groups: labor, feed, and all other. Labor costs are the cash payments to hired workers and to family workers whenever a formal wage agreement existed, as in the case of older sons. These costs include the wages, usually paid on a monthly basis; the payments for social security compensation and other insurances; the rental value of housing; and the farm value of food. Wage rates vary with individual sltuations. The most common wage paid to specialized milkers was $\$ 375$ per month; some milkers received as much as $\$ 435$. Included in these wages were holiday and sick leave benefits, as well as occasional bonuses which were paid when superior work techniques could be tied to some measurable factor such as low bacteria count or gain in butterfat production. Wages of yardmen and general workers varied considerably. A general average was about $\$ 250$ per month. Labor costs as defined above averaged $\$ 3,368$ 
per farm in the Group I dairles--8 percent of cash operating costs-and $\$ 10,056$ per farm in Group II--12 percent of those costs (Table 14). Feed costs include the expenses for all purchased feed supplies. This cost item overshadowed all other cost components. In Group I, 60 percent of the total cash operating costs were for forage and concentrates. The average per farm was $\$ 25,772$, with about three-fifths for forage and two-fifths for concentrates. For Group II, feed costs accounted for 57 percent of the total for an average of $\$ 49,262$ per farm. In this group, concentrates contributed relatively more to feed costs than in Group I (Table 14).

Slightly more than 30 percent of the cash operating costs were for other materials and services associated with the dairy herds. These items varied from supplies to taxes and are summarized in broad groups in Table 14. All are self-explanatory to those familiar with dairying. The average per farm in Group I was $\$ 13,840$ and in Group II was $\$ 26,443$. Cash operating costs per cow averaged $\$ 374$ in Group I and $\$ 435$ in Group II. The difference between means was highly significant even though the dispersions around the means were high. In Group I, the range was from $\$ 272$ to $\$ 484$ per cow, with a standard deviation of $\$ 32$. The range in Group II was from $\$ 336$ to $\$ 513$, with a standard deviation of $\$ 49$.

Annual noncash costs are payments made over a perlod of time to the farm operator to compensate him for the deterioration of certain resources through depreciation and obsolescence and for a minimum opportunity cost for capital invested in the business. There is a great deal of arbitrariness in their application and amount, but analysts charged with developing a cost structure recognize the need for some compensation. 
TABLE 14

Average Annual Cash Operating Costs Per Farm by Farm-Size Groups Marin and Sonoma Counties, California, 1960

\begin{tabular}{|l|r|r|r|r|}
\hline \multicolumn{1}{|c|}{ Type of cost } & \multicolumn{2}{c|}{ Group I } & \multicolumn{2}{c|}{ Group II } \\
\hline & dollars & percent & dollars & percent \\
\cline { 2 - 5 } Labor & 3,368 & 8 & 10,056 & 12 \\
Feed (all, purchased) & 25,772 & 60 & 49,262 & 57 \\
Forages (hay equivalent) & $(15,130)$ & & $(27,222)$ & \\
Concentrates (all) & $(10,642)$ & & $(22,040)$ & \\
Other & 13,840 & 32 & 26,443 & 31 \\
Custom work & 138 & & 272 & \\
Crop expenses & 326 & & 794 & \\
Gas, oil, and auto & 926 & & 1,521 & \\
Livestock purchases & 647 & & 2,906 & \\
Rent & 1,706 & & 1,636 & \\
Repairs and maintenance & 1,008 & & 1,720 & \\
Supplies & 608 & & 1,502 & \\
Health and breeding services & 1,100 & & 2,123 & \\
Taxes & 1,231 & & 2,495 & \\
Insurance & 415 & & 957 & \\
Interest & 625 & & 1,136 & \\
Utilities & 748 & & 1,198 & \\
Trucking & 3,687 & & 6,727 & \\
Miscellaneous & 603 & & 1,456 & - \\
Total & $-32,980$ & 100 & 85,761 & 100 \\
& & & & \\
\hline
\end{tabular}


On the sample farms, 5-percent anmual depreclation was computed on the average inventory values of buildings and equipment. This percentage was chosen in recognition of the high obsolescence in these resources and the need to revise them, as price relationships might contimue to favor the substitution of buildings and equipment for labor. No depreclation was computed on land as this resource is not losing its basic fertility or capacity. As herd sizes are being maintained or even increased, no depreclation was applied to this resource. The cost of maintaining the herds appears in the cash operating expenses, and livestock purchases and sales are taken into account. The average depreciation allowance computed per farm was $\$ 2,375$ for Group I and $\$ 2,807$ for Group II (Table 15).

A 5-percent interest allowance was made on the owner's equity in the land, livestock, buildings and facilities, and equipment. This averaged \$5,536 per farm in Group I and \$10,563 per farm in Group II (Table 15). Interest on borrowed capital secured by these resources was included in the cash payments. Operators who rented part or all of their farms had rental payments attached to the use of such resources.

\section{The Returns}

Because of the extent of specialization, returns are limited almost entirely to income from the sale of milk and dairy animals. The minimum price of market or Grade A milk is set by the Bureau of Milk Stabilization and in 1960 was as follows for 3.8-percent butterfat millk f.o.b. plant at San Francisco. 


\section{TABLE 15}

Type of Production Costs and Annual Average Per Farm by Farm-Size Groups, Marin and Sonoma Counties California, 1960

\begin{tabular}{|l|c|c|c|c|}
\hline \multicolumn{1}{|c|}{ Type of cost } & \multicolumn{2}{|c|}{ Group I } & \multicolumn{2}{c|}{ Group II } \\
\hline \multirow{3}{*}{ Cash operating } & dollars & percent & dollars & percent \\
\cline { 2 - 5 } Noncash allowances & 42,980 & 84 & 85,761 & 86 \\
Depreciation & 7,911 & 16 & 13,370 & 14 \\
Interest & $(2,375)$ & & $(2,807)$ & \\
Total a/ & $(5,536)$ & - & $(10,563)$ & - \\
Costs per cow - & 50,891 & 100 & 99,131 & 100 \\
$\begin{array}{l}\text { Cost per hundred- } \\
\text { weight of 4 percent } \\
\text { fat-corrected milk }\end{array}$ & 4.59 & & 503 & \\
\hline
\end{tabular}

a/ Does not include value of unpaid family labor or payment to operator for labor and management service. These differences preclude direct comparison with cost data furnished by the Bureau of Milk Stabilization or private accounting firms in the state. 


\begin{tabular}{|l|c|c|c|}
\hline & Butterfat & Skim milk & Whole milk \\
\hline \multirow{2}{*}{ January 1 to March 31 } & $\begin{array}{c}\text { dollars } \\
\text { per pound }\end{array}$ & \multicolumn{2}{|c|}{$\begin{array}{c}\text { dollars per } \\
\text { hundredweight }\end{array}$} \\
\cline { 2 - 4 } April 1 to August 31 & 1.03 & 1.95 & 5.79 \\
September 1 to December 30 & 1.03 & 1.63 & 5.33 \\
\hline
\end{tabular}

From this schedule it is possible to determine the price of milk with higher or lower butterfat tests. Premiums by some companies can alter the price in recognition of special qualities in the milk. That portion of the milk which goes for manufacturing purposes mist receive at least the manufacturing price which, on a hundredweight basis, was as follows in 1960:

$\begin{array}{llllll}\text { January } & \$ 3.40 & \text { May } & \$ 3.06 & \text { September } & \$ 3.23 \\ \text { February } & \$ 3.33 & \text { June } & \$ 3.04 & \text { October } & \$ 3.37 \\ \text { March } & \$ 3.20 & \text { July } & \$ 3.04 & \text { November } & \$ 3.43 \\ \text { April } & \$ 3.09 & \text { August } & \$ 3.09 & \text { December } & \$ 3.45\end{array}$

The average annual price, weighted on the basis of monthly recelpts of manufacturing milk from Marin and Sonoma counties, was \$3.22.

In Group I the average annual production per cow was 9,720 pounds of milk and 412 pounds of butterfat. Using the schedule of prices for market milk and a monthly weighting in accordance with the Grade A usage of milk from Marin and Sonoma counties ( 91.5 percent) and adding the value of the manufacturing portion of the milk ( 8.5 percent), the value of this output was $\$ 562$ or $\$ 5.78$ per hundredweight. Using these rates, the returns from milk sales for a herd equaling the average size in this group ( 115 cows) would be $\$ 64,630$ (Table 16). Milk sales constituted 
TABLE 16

Estimated Average Gross Returns Per Farm by Source and Farm-Size Groups, Marin and Sonoma Counties California, 1960

\begin{tabular}{|l|c|r|r|r|}
\hline Source of return & \multicolumn{2}{|c|}{ Group I } & \multicolumn{2}{c|}{ Group II } \\
\hline \multirow{3}{*}{ Milk } & dollars & percent & dollars & percent \\
\cline { 2 - 5 } Livestock & 64,630 & 93 & 115,245 & 91 \\
Other & 4,525 & 6 & 10,230 & 8 \\
Total & -380 & -1 & -840 & 1 \\
& 69,535 & 100 & 126,315 & 100 \\
\hline
\end{tabular}


93 percent of all estimated returns. 1 This assumes, of course, that all dairymen in the sample have contracts which result in the same proportions of milk having exactly the same market usage as for the entire area. Such is not the case, but many do closely resemble the general market-use situation.

Average production per cow in the herds included in Group I ranged from 7,017 to 12,454 pounds. The butterfat test average was greatly influenced by the breed composition of the herd and varied from a herd average of 3.68 for one Holstein herd to 5.10 for a herd of Jerseys. The range in returns was from $\$ 38,000$ to $\$ 91,000$, but incomes for 50 percent of the ranchers in the group were within $\$ 10,000$ of the group average.

Average annual production per cow was 10,040 pounds of milk and 430 pounds of butterfat per farm in Group II. The highest herd average of a.l 40 farms was found in this group; an output of 12,612 pounds of milk and 496 pounds of butterfat was achieved on a herd of 190 cows. The lowest herd average was 7,184 pounds of milk and 348 pounds of butterfat. Ten of the 20 operators achieved an average output per cow of over 10,000 pounds in terms of 4 percent fat-corrected milk.

Using the same basis for calculating returns, the value of the average output was $\$ 585$. The returns from milk sales on a herd equaling the average size (197 cows) in this group would be $\$ 115,245$ (Table 16). Estimated returns from milk sales ranged from $\$ 91,000$ to $\$ 143,000$ in the group. Again, milk sales constituted the major part of all estimated returns in the group.

I) Returns data were not collected from the ranchers. Only physical quantities were recorded, and general prices have been attached to these. 
Sales of dairy animals were mainly of two types: young calves, primarily bulls, and milk cows culled from the herds for various reasons. Several dalrymen had surplus replacement stock for sale to other dairymen as producing animals. Most calves are sold a few hours after birth and return $\$ 1.00$ or $\$ 2.00$ each. The overall replacement rate for both groups was 31 percent per year, but only 28 percent of these are sold. The value per animal varles with the beef market situation and weight of the animal. Auction markets are the main outlet. Returns per head have ranged from $\$ 80$ to $\$ 160$. A general average of $\$ 125$ was used in estimating returns per farm. Most heifers are used for replacements by culling the lower producing cows, but some surplus was sold through cattle dealers. Well-grown, healthy animals bred to enter milking herds ranged in price from $\$ 175$ to $\$ 260$. In computing returns per farm, an average of \$225 was used (Table 16).

Incomes from other sources were meager. One operator sold some manure, several obtained small government payments for the use of fertilizers, and others recelved rebates from the cooperative to which they belonged.

\section{The Flow Concept}

Few agricultural activities lend themselves so well to a diagrammatic presentation of the production flow process as do the dairy ranches of California. This is true largely because a high proportion of the productive goods and services used are purchased by managers from off-farm sources.

Presenting the flow processes is more complex for dairying in the study area than in other areas such as Los Angeles. Like the managers, we can visualize a basic production plant that has a location with only 
enough land to permit easy operation around the necessary buildings and facilities. These include the milking center, lanes, corrals, feed racks, and feed storage buildings. Added to this plant is equipment designed to facilitate high technical efficiency of the labor crew in milking, concentrates feeding, and cleaning. Finally, the dairy herd 1tself is housed in the plant to complete the productive unit.

Into the plant flow inputs of goods and services from sources off the farm and from other farm enterprises composing the total farm complex. These include all items used in production which are purchased from various markets or are grown on other parts of the ranch, such as hay; concentrates; gas; oil; and the services of milkers, repairmen, and veterinarians. Typical enterprises found on dairy ranches are the livestock replacement enterprise and the forage enterprise. These provide replacement stock and pasture and hay for the dairy herd. In turn, each of these enterprises requires some input flows of productive resources from farm and nonfarm sources.

Outputs, in the form of milk, flow from the productive unit to offfarm markets and, in the form of calves and manure, flow to the internal enterprises on the ranch.

The major external and internal flows have been illustrated on Figure 8. In this diagram, important physical inputs and outputs have been identified, and an approximation of their economic values is shown by the width of lines leading to and from the plant.

Dairy ranchers stress the business concepts of dairying and visualize them much as they have been presented in the flow diagram. Management decisions are made with these concepts in mind. Given certain restrictions and indivisibilities in several of the input factors, particularly 
Figure 8. Schematic Input-Output Flow on Representative 115-Cow Dairy Ranch, Californ1a, 1960

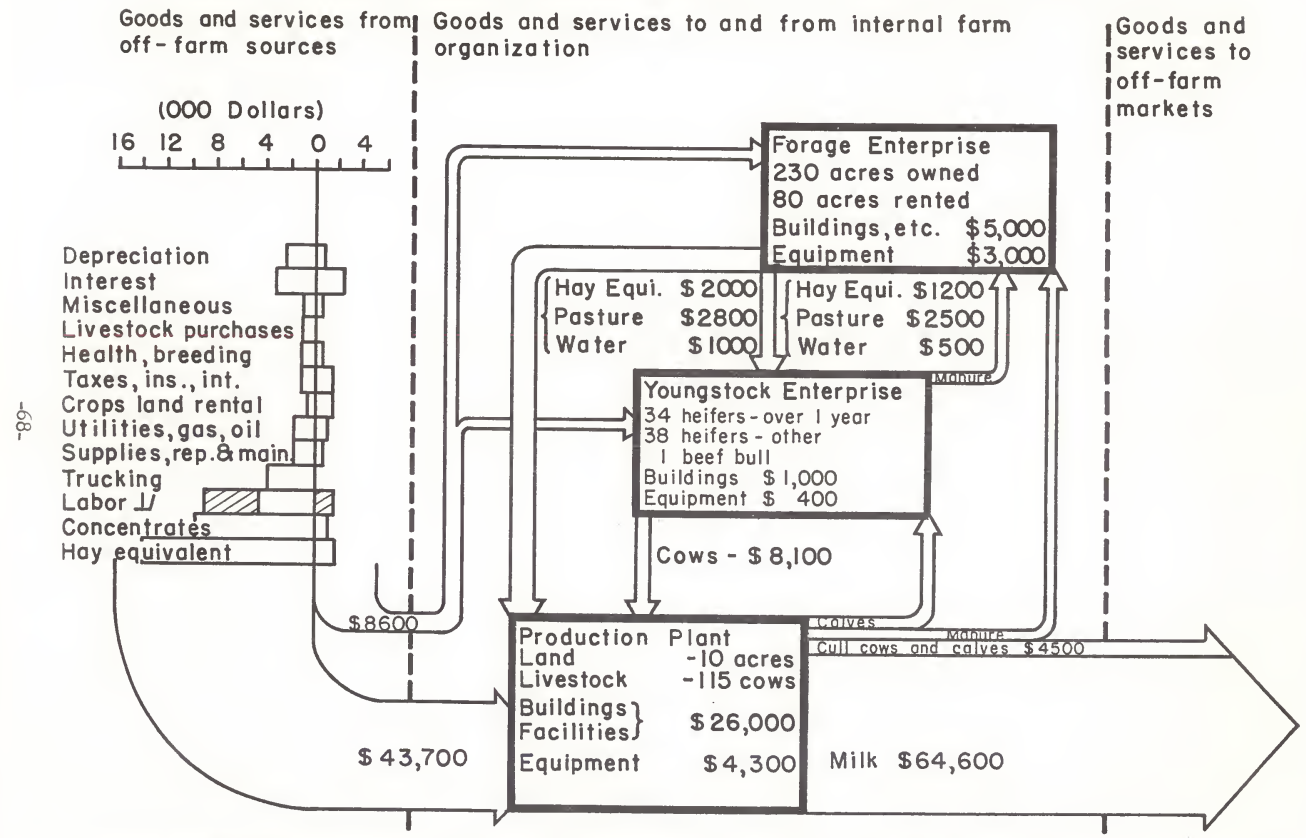

If Value of management ana labor contribution of owner and his family not included as a cost. 
labor, ranchers attempt to maximize milk output of the fixed plant within economic limits. In doing so, their actions follow closely the concept of equating marginal costs and marginal returns. Feeding and culling practices are highly conditioned by this attitude, although, of course, it is not formally identified, nor can it be approached to a precise degree. 


\section{DEVELOPMENIS IN FORAGE PROCUREMENT AND USE}

The patterns of forage procurement and use on farms in the study area have developed over a period of time and have been Influenced by forces both within and outslde of agriculture. Changes which will in fluence present forage patterns are under way, and these ranchers are faced with many new decislons. Their actions will be conditioned by the historical developments in the area and the institutions impinging upon their businesses.

\section{A. Role of Pasture}

Many of these ranchers hold huge areas of land which were acquired in previous years. They will continue to hold and use this land until such time as nonagricultural uses may successfully bid for these resources. Because of the general lack of water and the rolling topography in the area, there w1ll probably be little emphasis on irrigation. The natural pasture plants are best adapted to the weather and land conditions, and pasturing will probably be the main usage of these areas for the near future. Several questions might be raised about the use of these pastures.

First, is it profitable for dairymen to continue to use these pastures much as they are now doing, that is, by obtaining some forage for the producing herd and by raising replacement stock largely on the pastures, as shown in Figure 8? For the average situation, the answer is yes, it is profitable. For example, in Figure 8 , it is shown that the annual cash operating and noncash costs which could be allocated to the land and young stock enterprises were $\$ 8,600$. From these enterprises, 
goods and services to the extent of $\$ 12,900$ (not including any value for the water supply service) flowed to the production plant. It is recognized that certain arbitrary decisions were made concerning cost allocations, but a realistic treatment was given and the flows to and from these enterprises are reasonably accurate.

However, we might go further and show how costs and returns of the production unit would change if the land and young stock enterprises did not exist. All flows to and from these enterprises would cease and, to compensate for their loss, the flows of goods and services from the offfarm sector would increase. A budget was prepared of the estimated changes in the cost of these flows and a summary is given in Figure 9. The scale is similar to the previous figures so that relative changes can be visualized. The effect of the various changes in flows resulted in a decline in net income to the manager and his family of approximately $\$ 4,000$. For specific farm situations, the benefits of the young stock and land enterprise would vary from this estimate. But under the conditions of the central coastal region, dairy ranchers generally find it profitable to use their land areas for replacement stock and pasturage.

A second question regarding the future use of pastures is related to the possible increased utilization of pastures by the producing herd. This could be accomplished in several ways--more producing cows might use the available pasturage, more cows might use the pasturage increased through fertilization, and more cows might replace some or all of the replacement stock on pasture. On any particular ranch, some possibilities might exist for any of the above actions but, in general, they would not be used unless certain changes occur in the institutions affecting dairying. Each producer has a quota for the amount of market milk which 
Figure 9. Schematic Input-Output Flow on Representative 115-Cow Drylot Dairy Farm, California, 1960

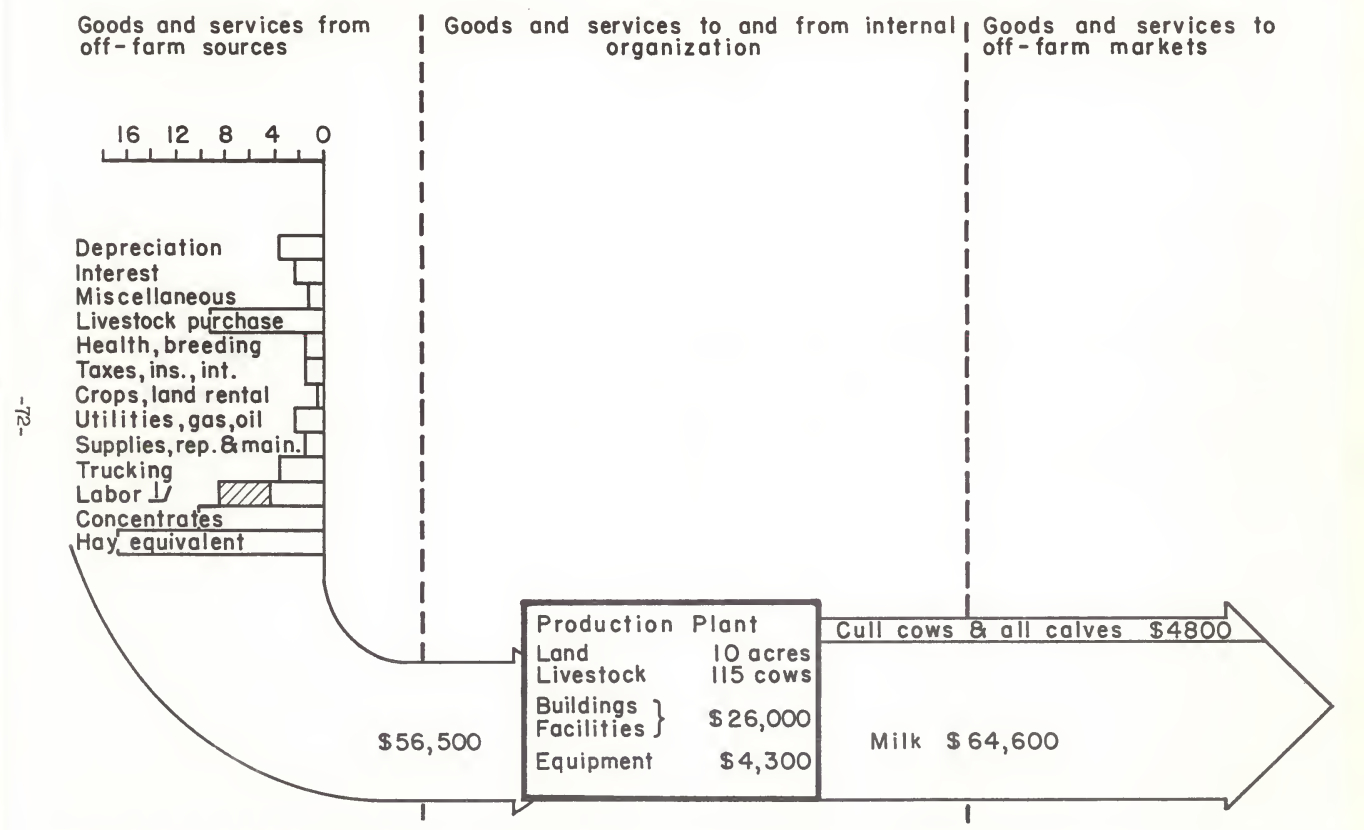

1/ Value of management and labor contribution of owner and h1s family not included as a cost. 
he can deliver, and each attempts to produce at or slightly above this quota. Expansion of the producing herd depends upon a shift in the contract rather than the availability of pasture. Observations in the field would indicate that excess pasturage exists on most ranches during the flush season. Practically no fertilizer other than manure is used, and it would be difficult to apply on many of the hillsides: Unless the plant population were altered, fertilizer would tend to magnify the peak production period without greatly altering the seasonal distribution. An experiment to test the effects of range fertilization made in an adjacent area showed that total production was increased substantially over that in areas receiving no fertilizer (Table 17). 1 / on most ranches, however, the heavy applications of stable manure in accessible areas already result in additions of nitrogen, phosphorus, and potassium at levels comparable with those shown in the table. A significant finding of the experiment was that the stands fertilized with commercial materials matured earlier than nonfertilized stands and were actually dry by late May. Therefore, some gains made at the beginning of the pasture season might be nullified by excessive growth in the peak period. This growth would become overmature and reduce usable later growth. Under the reduced flexibility resulting from contractual arrangements, the use of pastures by the replacement stock, except during periods of peak growth, appears to be the best economic adjustment.

Finally, with regard to future use of pasture, we might consider whether a dafryman with limited capital should put funds into the forage and young stock enterprises if he were to start operations from a new

1/ Cyrus M. McKell, Jack Major, and Eugene R. Perrier, "Range Fertillzation of Annual Forage Plants," California Agriculture, vol. 15, no. 5, May, 1961, pp. 5-7. 
TABLE 17

Response of Annual Range Vegetation to Specified Fertilizer Applications, California, 1960

\begin{tabular}{|c|c|c|c|c|}
\hline \multirow{2}{*}{} & \multicolumn{4}{|c|}{ Treatment } \\
\cline { 2 - 5 } & $\begin{array}{c}\text { No } \\
\text { lizti- }\end{array}$ & $\begin{array}{c}\text { Phosphorus } \\
\text { 200 pounds } \\
\text { per acre }\end{array}$ & $\begin{array}{c}\text { Nitrogen } \\
150 \text { pounds } \\
\text { per acre }\end{array}$ & $\begin{array}{c}\text { Combina- } \\
\text { tion } \\
\text { of both }\end{array}$ \\
\hline $\begin{array}{c}\text { Inches of rainfall } \\
\text { (October-June) }\end{array}$ & 17.01 & 17.01 & 17.01 & 17.01 \\
$\begin{array}{c}\text { Yield in pounds } \\
\text { per acre }\end{array}$ & 1,440 & 1,704 & 3,169 & 5,929 \\
\hline
\end{tabular}

Source: Cyrus M. McKell, Jack Major, and Eugene R. Perrier, "Range Fertilization of Annual Forage Plants," California Agriculture, vol. 15, no. 5, May, 1961 , p. 5 . 
location in the area. The production plant of the representative farm calls for an investment of $\$ 64,000$. If used as a drylot dairy, returns would be $\$ 69,400$ and costs would average $\$ 56,500--l e a v i n g$ a net of $\$ 12,900$. When the pasture and young stock enterprises are managed at the average intensity discovered in the survey, 290 acres of pastureland would be used (cropland and 1ts input-output flows were eliminated from these calculations) and 73 head of other livestock would be pastured. The total additional investment, at assumed inventory rates, would be $\$ 70,000$. Net returns for the more comprehensive production plan including milk, replacement stock, and pesture would be $\$ 17,000$. By more than doubling the investment, an addition of about $\$ 4,000$ or a 30 percent increase was made to net income. If a dairyman had limited funds, say $\$ 134,000$, he could organize a unit with pasture and young stock as identified above and expect a net of $\$ 17,000$. However, if he had a market for the milk, he could, at a minimum, organize two drylot units of 115 cows each for slightly less total investment and obtain a net of $\$ 26,000$. A preferable organization would be one unit of 230 cows to realize economies of size in investment and operation procedures.

In the above example, the cost of pastureland was estimated at $\$ 200$ per acre. In order for the investment in pasture and replacement enterprises to be equally as profitable as the milk enterprise per dollar of Investment, pastureland would have to cost no more than $\$ 32$ per acre.

\section{B. Technological Changes}

Changes are under way in other segments of forage procurement which may have ramifications upon dairy herd management. Two developments in hay harvesting may alter the cost situation. One is the introduction of 
the self-propelled windrower, commonly called a swather; the other is the exploratory developments in the cubing and wafering of alfalfa hay.

The swather cuts, conditions, and windrows hay in one operation. Cost advantage accrues over the mowing and raking method usually used if more than 500 acres are cut annually (each cutting counted separately). Labor and machine costs are estimated to be from $\$ 0.60$ to $\$ 1.00$ per ton less for growers of typical acreages in the alfalfa producing areas. If While this is not a major cost adjustment, this reduction in cost, together with possible quality improvements which are indicated, could result in an increase in net income to dairymen if the cost benefits are passed on to the bay buyer. Cubing and wafering of alfalfa is still in an exploratory developmental phase. Several companies have machines in operation, and output is sufficient so that several dairymen feed their producing herds entirely on hay processed by these methods. Some machines process the hay from windrows in the field as a regular baler, others process at a fixed location. No real tests of nutritional or cost benefits have been made. At present, the cubed alfalfa is delivered at the farm at $\$ 5.00$ more per ton than comparable baled alfalfa hay. Farmers who feed this forage claim that milk production is increased, that there is less waste, and that, as the cubes have a lower moisture content, more usable feed is purchased per ton. No controlled experiments have been completed to substantiate or refute these claims. An experiment is scheduled to start in 1962 at the California Experiment Station at Davis to discover answers to some of these questions. Several apparent advantages are associated with this form of processing hay.

If R. A. Kepner, J. R. Goss, and L. G. Jones, "Hay Harvesting by SelfPropelled Swather," California Agriculture, vol. 15, no. 5, May, 1961, pp. $1-4$. 
The resulting product will flow by any of the usual methods used in handling bulk materials, and $1 t$ occuples about one-third of the space required by baled hay. These characteristics give obvious cost advantages in loading and transporting the material to farms, unloading, storing, and feeding. Under present conditions, at all points in the distribution and feeding process, techniques, buildings, and equipment have not yet been developed to take full advantage of these flow advantages. However, this would appear to be one of the important current changes in the procurement and use of forage, and California dairymen may well turn to this material in their contimal search for cost reduction methods in milk production. Benefits in laborsaving are illustrated in Figure 10. 
Figure 10. Typical Methods Used in Handling Alfalfa Hay in Conventional Bales and in Cubes

Conventional bales:

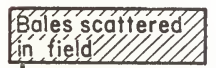

Load by hand -2 men, truck, bale loader

Cubes:

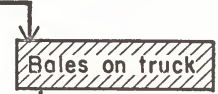

Move to roadside and unload by hand, 2 men,truck, stacker
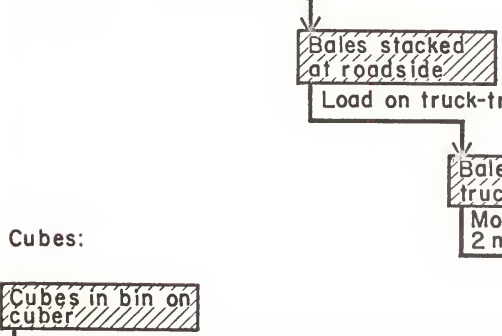

Load on truck-trailers -2 men, truck-trailers<smiles>C1C[C@H]2CC12</smiles>

Eales on

truck-rrailers

Move to ranch $Q$ unload by hand2 men, truck-trailers

Dump in truck-trailers-I man, truck trailers

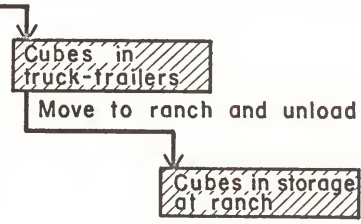

mechanically, I man, truck-trailers, elevator 


\section{SUMMARY AND CONCLUSIONS}

Dalrying is one of the major agricultural industries in California. The sale of milk and milk products accounts for 12.5 percent of the total income from the sale of all agricultural products and totals approximately $\$ 375$ million annually. This industry depends largely upon feed supplies grown within the state. It competes with other livestock industries and nonagricultural users for these supplies. About 21 percent of the total supply of concentrates available for animal feed, including considerable imports, and about 62 percent of the total storable forage supply are used for dairying. Most of the forage is produced within the state, primarily as sun-dried alfalfa hay grown in Irrigated areas of the San Joaquin and Sacramento valleys. Only 2 to 3 percent of the total supply is imported from adjacent areas, primarily Arizona.

California dairy ranchers have developed a unique and interesting industry. The individual producing herds are much larger than those found in other parts of the nation. A heavy dependence is placed upon purchases from off-farm sources of more production supplies or inputs. In some areas, all forage needs as well as concentrates are purchased. Technical input-output efficiency is high. For example, average milk production per cow is the highest of any state in the nation--8,950 pounds in 1960 . Although data are not available, doubtless milk production per man-hour would also be the highest because of the large herds and specialization on milk production itself. The net returns to the managers are favorable for those who have contracts to sell a high proportion of their milk as market milk.

A sample of 40 dairymen was drawn from a universe of slightly more than 400 dairy ranches in Marin and Sonoma counties, which are located in 
the central coastal district. The sample represented two strata--those dairymen having approximately 100 cows and those having approximately 200 cows. Physical input-output information and cost data were obtained by personal interview and results were summarized. Cash outlay for forage was the largest single operational cost per farm, and food concentrate was second largest. Together they constituted nearly 60 percent of the average operational cash costs in both groups. Forage purchases were primarily for alfalfa hay, although small quantities of other hay and green chopped alfalfa were bought. Some of the dairymen grew some oat hay or corn for silage but, in average terms, less than 10 percent of the hay needs were grown. Pasturage furnished about 30 percent of the forage needs of the milking herd during a three-month period and two-thirds of the total. annual forage needs of the replacement stock. Labor made up 8 percent of cash costs in Group I. (the smaller sized herds) and 12 percent in Group II. In Group I, the operator and his unpaid family workers averaged 55 percent of the total labor force; in Group II, they were 31 percent of the total. force. All other cash operating costs averaged about one-third of the total cash costs in both groups. Noncash ownership costs were allocated for the use of fixed productive resources. These accounted for approximately 15 percent of total costs.

Returns were calculated by taking physical outputs and applying average prices and utilization rates. Because of the extensive specialization, milk receipts made up over 90 percent of all income in both groups. Expense and income flows were developed for a representative firm in Group I. For every $\$ 1.00$ of income there were cash and noncash costs of $\$ 0.76$ when the values of managenent and the labor contribution of the owner and his family were not included as costs. 
The patterns of forage procurement and use which have developed in California are the result of the interaction of several unique phenomena in the environmental setting of milk production. In brief, these are as follows: Certain areas near markets developed dairying at an early period. With population expansion these dairymen increased in size, and rather than produce their forage they found it more profitable to buy hay from areas opening up to agriculture by development of great Irrigation systems and superior highway transport systems. These new areas were naturally endowed from the standpoint of fertility and topography to grow crops and to sun-dry excellent alfalfa hay. With improvements in milk transport facilities, milk production has tended to move closer to the alfalfa producing areas. But the contractual system in milk marketing, the opportunity costs of agricultural alternatives, and the managerial skills required in efficient milk production have tended to restrain this movement.

Major shifts in procurement or utilization patterns are not expected in the study area. Restrictions to major expansions exist in herds through contractual marketing arrangements for milk. In some areas, pastures are now used to provide forage for the producing herd for a short period and to support the replacement stock. The present use contributes to the net income, and more intensive use of pastures will occur if farm quotas for milk are raised. It is unlikely, however, that these ranchers will return to the production of stored forages. Several new developments in hay production techniques may eventually have a cost-reducing impact on dairy ranches in the study area. These developments are still in an exploratory phase, and their eventual influence is promising but still uncertain. 
